\title{
Belong, but don't be-long: Narratives of youths sponsored by former participants of the Live-in Caregiver Program
}

by

\author{
PJ Javier
}

A thesis submitted to the Faculty of Graduate and Postdoctoral Affairs in partial fulfillment of the requirements for the degree of

\author{
Master of Arts \\ In \\ Institute of Women's and Gender Studies \\ Carleton University \\ Ottawa, Ontario \\ (C) 2021, PJ Javier
}




\section{ACKNOWLEDGEMENTS}

It is depressing to think "you're my favorite teacher" translates to "you treat me like a person." I want to thank the Institute of Women's and Gender Studies for treating me like a person as everyone in the department is my favorite teacher. Thank you for your patience, your wisdom, and understanding as you have all seen me grow within the past six years; learning and thinking with the most brilliant faculty and staff have been so important for my growth. Thank you to everyone for believing in me even when I sometimes had trouble believing in myself. Thank you for showing me my potential, and equipping me with the tools to successfully move forward beyond the confinements of Dunton Tower.

I want to thank my friends, Rachel Jobson, Delphine DiTecco, Caitlin Hart (Ummni Fan Club) for taking me under your wings and always guiding me as I make steps in the right direction. My developing frontal lobe and my stubborn attitude are forever grateful.

Thank you to Shannon Srivastava, Jaclyn Houad, Nicole Kiluk, and Ali MacPherson for supporting me throughout this journey.

I want to thank my co-supervisor Ann Cvetkovich. I have never shed so many tears in a class except yours; I say this with profound gratitude. Thank you for teaching me to how to always dig deep, find meaning in every word, and for reminding me that discomfort is a small price to pay for growth.

I want to thank my mentor, friend, supervisor, and all the other roles she has served in my life. Amrita Hari, thank you for your research, thank you for your patience, thank you for teaching me not only about what books to read, how to write, but most importantly - thank you for teaching me how to be a better person. You have shown me how to live with strength and integrity. Thank you for teaching me things that the academy could not but should. 
Lastly, I want to thank Patricia Callahan for teaching me how to have fun. You have opened my eyes to a life full of adventure beyond my imagination. Thank you for reminding me not to take life too seriously, to relax, and most importantly, thank you for making me laugh. Laughter really is the best medicine, and I am glad I have got a lifetime supply with you by my side. 


\section{TABLE OF CONTENTS}

Title Page.

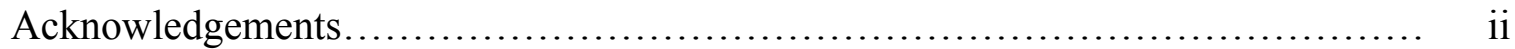

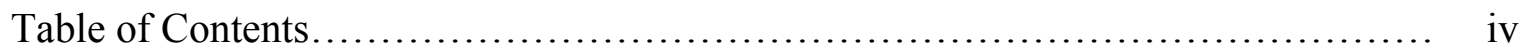

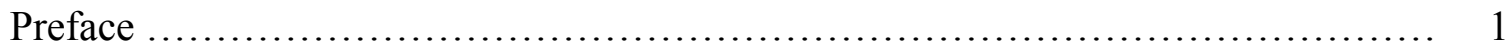

Understanding history to plan for a better tomorrow.............................. 8

The 'then' and now of the Philippines..................................... 9

The 1992 Live-In Caregiver Program (LCP) ........................... 10

Deskilling Filipinx migrants ............................................ 12

The 2014 Caregiver Pilot...................................................... 13

The 2019 Care Pilot ................................................. 16

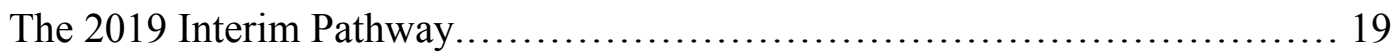

Writing Myself into Theory - Childhood as a Lifetime Experience................. 21

Transnational Hyper-Maternalism....................................... 23

Childhood Innocence................................................... 28

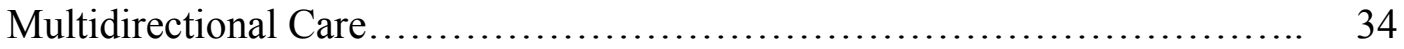

I am them and they are me, sometimes! Moving Together as Research Method.... 37

Documenting their lives with care.......................................... 39

Importance of everyday objects......................................... 40

I feel them, they feel me: My emotional research.......................... 41

This is for my Mom": Sacrifices and Aspirations................................. 45

The best of both worlds: Moving and grooving ............................ 49

Hear me Out!: Transnational Hyper-maternalism and "Cluster of Promises" ... 53

Understanding emotional fluidity: What goes around, comes around ............ 55

Help! Everything in My Life is Turning Queer!................................................... 59

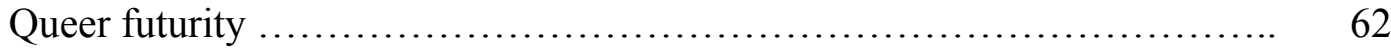

The magic of storytelling ............................................. 66

When the Nu(clear) Family isn't so clear.....................................69

Lisa's family ties ...................................................... 71

Multidirectional care in Lisa's family ................................. 75

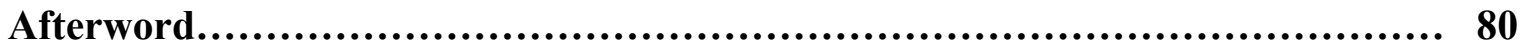

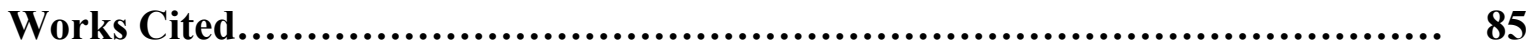


Appendix A: Interview Guide................................................. 90

Appendix B: Demographics............................................................. 93 


\section{PREFACE}

Mabuhay! is a Filipino greeting, which means welcome! Welcome to this thesis; welcome to these stories. I am happy that you are here. It is strange to think that this research project was born because I was in pain. I no longer wanted to be the racialized student who left the classroom to go cry in the hallway just because the topic under discussion happened to be "Migrant Women's Labor" or related topics. I recognize that migrant women and their contributions to global chains of care are popular topics in Women's and Gender Studies and other critical disciplines - as they should be. This is a topic and discipline which I have intimate knowledge of; I have studied and been a part of this discipline for six years now. So, given the inevitability of the topic, and also my years in the discipline, you can only imagine the number of times that I left the classroom.

Although this project may have brought me many tears, I am incredibly thankful for those tears because they served as a powerful research method and personal motivation to pursue this project. My tears further served as a catalyst for a larger ideological question that interrogates the ways in which children of transnational families see themselves. We, myself as the researcher and the participants as co-producers of this thesis, gave each other permission to share and write down our lived experiences outside of the way it is taught in post-secondary education in Canada.

Before my journey with this thesis began, everything I learned about the Philippines and my identity from my formal education was related to poverty, the sexualization of Asian women, and representations of Asian women as quiet, respectable, and hardworking. As I learned more about the Philippines in my Women's and Gender Studies classes, the portrayals of the nation and its citizens often boiled down to Filipinx women as caregivers and caregivers only. 
This reductionist portrayal or single story drove me to start this project. I wanted to rewrite the narratives that I have read, heard, and seen about the Philippines and Filipinx ${ }^{1}$ women as a single category. I wanted to move away from the literature that focuses on the trauma of family separation and family reunification, and instead, start writing about beauty, love, and affection, and the ways in which Filipinx people will always make a home wherever they find themselves because kahit magkalayo kami, hinid kami magkahiwalay. This is literally translated as "even if we are separated, we are never apart". I found this quote by an unknown author in Valerie Francisco-Menchavez's book titled The Labor of Care: Filipina Migrants and Transnational Families in the Digital Age (2018) and was immediately drawn to it. Similar to FranciscoMenchavez and this unknown author, I wanted to tell a different story of family, belonging, and migration.

Casey Mecija, in her work Blank Space and "Asymmetries of Childhood Innocence" uses a video of a child in an internet café in the Philippines singing to her mother on Skype who is working transnationally. The video is titled Kanta ng isang Anak para sa kanyang inang $O F W$ (Overseas Foreign Worker) "Blank Space" (translated as "Song of a child for her overseas foreign worker mother") (Mecija, 2020). I draw inspiration from Mecija (2020), in particular, learning from the creativity that the author uses to show us the ways in which pakikisama (the Tagalog word for being with) extends across cyber space and transnational borders. In this video, we see a young Filipinx child singing to her mother over Skype who then starts to cry when hearing her child's voice. Through this, we can see how there can be both comfort and pain when hearing the voice of someone we love. This thesis represents that song for me; the comfort and pain of having

\footnotetext{
${ }^{1}$ I use the term Filipinx to include my race as a Philippines citizen while also encompassing the multifaceted gender and sexual identities I explore.
} 
my voice heard by the many communities I belong to as the child sponsored by a former participant of Canada's Live-In Caregiver Program (LCP), a policy instrument that is central to the discussion presented here.

Now as an adult, I can explore, in collaboration with Mecija (2020) and other critical thinkers, the deficiencies and exclusions of normative theories of child development. Mecija (2020) argues that these normative theories assume that the physical presence of the mother is needed for developmental success, but as you will see throughout this thesis, my life, and the lived experiences of my participants, fall outside of the categories and ideas that inform normative theories of child development. This is because our experiences are adjacent to colonialism and increasing globalization. Yet, despite family separation and hardship brought by escalating poverty in the Philippines, Filipinx families still manage to find ways of spreading love across great distances. This project, born out of pain, finds its way to love across national borders.

The emotional effect of the Live-in Caregiver Program (LCP) deserves attention because care work destabilizes normative structures of family, nation, and community. Most importantly, Canada sees the program participants as hopeful migrants but treats them as disposable without taking into consideration the intergenerational trauma that the program is responsible for, which is also well documented in the literature on the topic (Baldassar 2007; Tungohan 2019; Pratt and Johnston 2014).

This thesis is written in a reflective and creative style with intention. It is important that you pause, just as I do, at every turn of writing, read the words, and reflect on the objects that my participants brought to our conversations. These objects are critical for their ability to be archived and to explain the properties of social life (Dyer., Mecija., 2018, p. 545). The artifacts presented here can invoke discomfort because art is political just as much as it is a reflection of life, fears, 
values, and experience. Most importantly, it is someone imagining the future. Each page of this thesis represents a 'future' that may be past for some and present for others. Overall, this thesis builds on the notion that childhood is not static but ongoing for my co-researchers and myself, as we make sense of our lives and futures.

This thesis is a result of my struggle for purpose. In my graduate school journey, I always struggled with finding purpose within the confinements of academic learning and research. The questions that I have always turned to when I needed to be reminded of my purpose include but are not limited to: What does my work do? Everyone works - but what does their work do? Who am I? How do I connect to others? How do I move forward with this information? I found these questions to be challenging as my answers changed every time. As I thought more about how to move forward with the information, including what I was learning in my classes, and through my own process of discovery from completing assignments to learning from what my participants shared, I have come to conclude that 'moving forward' is synonymous with giving back. My discovery of the materials I am learning is synonymous with learning about myself. Through this process of ongoing reflection, I have come to learn that I first need to know who I am before I know what my contributions to academia can be. If I am to act as a voice for the complex affective lives produced by the Live-in Caregiver Program (LCP), it is important for me to know who I am, as I am accountable to others who might have similar experiences that they share with me.

To queer something is to deviate from the norm. In this thesis, I use queer methods by centering emotion: an approach that can sometimes be discredited in comparison to positivistic approaches because emotions cannot be scientifically verified (McCann, 2016, p. 228). This thesis presents personal stories and affective responses of Filipinx youths as they internalize two modes of racism: their experience of their heritage being Filipinx, and the superiority of whiteness in 
Canada. My personal proximity to this thesis, and the emotions that arise, are validated through personal narratives shared between myself and my participants. Understanding my contribution involved a significant amount of reflection and reflexivity in order for me to believe that the commonness in our narratives is enough to count as valid and important knowledge. Hence, this qualitative study aims to center the voices of children often depicted as "left behind" in transnational literature and whose upbringing I argue is also left out of the normative theories of child development because colonialism made whiteness the ideal. I encourage anyone who engages with this thesis to get comfortable in the uncomfortable because it is discomfort that leads us to discovery and new understandings. I hope that you accept the complex and often messy counter narratives that this thesis embodies because it reflects my desire for social change.

The specific goal of this research project is to seek out the migration and settlement experiences of children who were sponsored for permanent resident status in Canada by former participants of the Live-in Caregiver Program (now the Caregiver Pilot Program). I use objectbased interviews to expand the limits of qualitative research methods by including the material and understanding its ability to 'speak' about a past worth telling (Woodward, 2016, p. 359). This project asks Filipinx youth how they negotiate their lives, identities, and familial/kinship relations, as they navigate their lives in Canada.

The participants in this study are self-identified Filipinx, between the ages of 18-30 residing in Ontario. They were asked questions about their everyday activities, relations, and engagements. The visual materials they brought to our conversations are objects they use and engage with in their everyday lives. With this project, I aim to contribute to the ongoing scholarly debates on the experiences of migrant workers and their children, and assist community organizations engaged in discussions of mental health and wellbeing among care workers and their 
families. This project has the potential to facilitate improved academic, policy, and popular understandings of this small but growing group of newcomers in Canada.

In Understanding History to Plan for a Better Tomorrow, following this preface, I contextualize the LCP and all of the different phases that the program has undergone, while also drawing connections to how histories of colonialism in the Philippines extend into the future of the nation and its citizens. In the Writing Myself into Theory-Childhood as a Lifetime Experience, I engage closely with Ethel Tungohan's concept of transnational hyper-maternalism, Hannah Dyer's utterance of childhood innocence, and Valerie Francisco-Menchavez's iteration of multidirectional care. I discuss how these concepts together speak to the realities of family separation from the perspectives of the children "left behind" in the Philippines to be later reunited with their families in Canada. Transnational hyper-maternalism speaks for Filipinx mothers, childhood innocence advocates for childhoods that are left out of normative theories of child development, and multidirectional care encompasses the labor, hardship, and longing that Filipinx families undergo in order to make the family function across national borders and great distances. Moreover, I am them and they are me, sometimes! Moving Together as Research Method deals with the relationship that I have to this project, my ethical considerations, as well as the process of gathering and telling my participants' stories. In this chapter, I justify the personal and political importance of this research project, and why the experiences that deviate from the norm are better told using queer methods such as object-based interviews.

In "This is for my mom": Sacrifices and Aspirations" you meet my first interview participant Vendeta. What I particularly enjoyed about Vendeta's interview was its complexity. Vendeta perfectly illustrates the realities of migrants who aspire to work themselves out of poverty. The concepts that helped me grapple with his story were Lauren Berlant's cruel optimism and 
Tungohan's transnational-hyper maternalism. These concepts together help me make sense of the problematic nature of the "American Dream" or in this case the "Canadian Dream" under neoliberalism, and what happens to this dream when it starts to impact families and their children.

In "Help! Everything in My Life is Turning Queer", I introduce Chini, whose childhood experience was more than extraordinary because he had the love and support of his queer community. His mother had to leave him with his homophobic father while she went abroad to become a caregiver. Through this turbulent time, it was his queer community in the Philippines that taught him everything there is to know about love, money, and sex. In this chapter, I include the work of child and youth studies scholars such as Hannah Dyer, Robin Bernstein, and Julie Garlen, who conclude that the concept of childhood innocence further perpetuates white supremacy because only white kids, and I would go as far as to say, white people more generally, are allowed to be protected under the guise of innocence.

In "When the Nu(clear) Family isn't so Clear", Lisa's familial dynamic adds to existing discussions within feminist political economy to make the argument that the nuclear family and capitalism work together to blur the lines between private and public life. And in the same breath, Lisa's family dynamic offers us a new perspective: the nuclear family is not the only way for families to operate. Adoption happens within families, care taking strategies are always shifting, and different family members take on various roles in order to make the family function.

I hope that you enjoy the stories you are about to encounter as they speak about profound resistance and hope. I wish that these stories offer you an understanding of the love, affection and care strategies that transnational families use to work themselves out of increasing poverty all while both the Philippines and Canadian government are trying to dispose of them. 


\section{UNDERSTANDING HISTORY TO PLAN FOR A BETTER TOMORROW}

While writing this thesis, I was introduced to an organization called Migrante Ottawa - which advocates for the rights and welfare of Filipino migrants and supports the struggles of Filipinx people in Canada. Migrante Ottawa estimates that over 6,000 Filipinx citizens leave the Philippines every day to find jobs overseas in order to support their families (Migrante Ottawa, n.d.). Migrante Ottawa has been a huge support for this project and for my personal development, as I learned the history of the Philippines through weekly meetings over Zoom. The organization helped me connect with the large Filipinx diaspora in Ottawa. Throughout this chapter, I will be citing heavily from the information gathered on their website because I owe a lot of my knowledge and the information presented in this thesis to the organization. I believe in and want to support the work that Migrante Ottawa is doing in helping other Filipinx migrants find a home within the diaspora.

This chapter echoes a large part of Migrante Ottawa's campaigns which focus on creating awareness about the problematic interactions between Philippine's Labor Export Policy and Canada's Temporary Foreign Worker Programs. Both these programs express the importance of care work, however, fail to protect Filipinx migrant workers who are the ones helping Canada fill supposedly urgent labor shortages, while simultaneously creating a reputable image of the Philippines as a country that was once rich in resources and opportunities. However, due to colonialism and its lingering effects, what was once a resource-rich and land of opportunities now functions mostly as a transnational labor hub exporting workers to countries like Canada that treat them as rotational and disposable. 


\section{The 'then' and now of the Philippines}

The Philippines is an agricultural country with a tropical climate; it boasts an ability to grow food all year round, and vital access to marine life (Migrante Ottawa, n.d), all of which became of interest to white settler colonies that emerged out of Europe in the nineteenth century, such as the United States, Canada, and Australia (Hari et al., 2013, p. 1). As a result, the Philippines, along with the United States (1898 - 1946) maintained a system of exchange that was both export oriented and import-dependent (Migrante Ottawa, n.d). This model meant that the Philippines had to export the country's natural resources for the use of industries in capitalist settler colonies. The Philippines continued to import their products consistently at an alarming rate. The exportoriented-import-dependent model also meant that there were no national industries to support and maintain the local and national Philippine economies, and as a consequence Filipinx citizens were left without stable jobs in their own country (Migrante Ottawa, n.d). "In 2018, the foreign debt of the Philippines was US $\$ 76.4$ billion. Debt service (interest payments) amounted to US $\$ 5.8$ billion that year" (Migrante Ottawa, n.d.). Job loss, precarious work, and the overwhelming amount of landlessness meant that balikbayan boxes, which were large boxes sent by overseas Filipinx workers that contained items such as clothing, food, books, and toys, were the only way that the Philippine economy was able to stay afloat.

Foreign labor export has been a longstanding practice of the Philippine government to maintain its economic vitality. The Philippines' role in the continuation of the Filipino labour export was largely influenced by President Ferdinand Marcos in 1974 (Migrante Ottawa, n.d.) The Marcos government formed bureaucratic institutions that overlooked migrant labour mobility: The Overseas Employment Development Board, the National Seamen Board, and the Bureau of 
Employment Services (Migrante Ottawa, n.d). These three bureaucratic institutions were supposed to be in service to migrants seeking labor abroad, but the Philippine government failed to protect their citizens when the demand for Filipinx labor overseas continued to rapidly increase over the years. As a result, these three institutions started to lose control and the private sector started to recruit Filipinx migrants. In 1982, the Philippine Overseas Employment Administration (POEA) was established, which combined the three institutions created in 1974 into one large bureaucratic body (Migrante Ottawa, n.d.). The sole purpose of this combined bureaucratic institution was to protect migrant worker's rights, yet even with these efforts, they still failed to adequately protect Filipinx migrant workers. What follows is an analysis of Canada's care demands and the relationship with the Philippines labor export policies in perpetuating cheap, rotational, and disposable labor at the cost of Filipinx lives.

\section{Live-In Caregiver Program (LCP)}

The LCP was established in 1992 and its purpose was to serve Canadians who were looking to recruit foreign nationals for childcare, home support, and other types of care work. The applicants had to meet the following criteria if they wanted to be eligible for permanent residency under the LCP program:

1. A positive Labour Market Impact Assessment (LMIA) from a Canadian employer

2. A written contract with [the] future employer, signed by [employee], and the employer

3. Successful completion of the equivalent of a Canadian secondary school education 
4. At least six months training or at least one year of full-time paid work experience as a caregiver or in a related field or occupation (including six months with one employer in the past three years)

5. Good knowledge of English or French

6. A work permit before [the worker] enter[s] Canada

7. 24 months of authorized full-time live-in employment in Canada, and

8. Work experience that must be acquired within four years of the original date of arrival. (Carlos, 2016, p. 4)

A Labour Market Impact Assessment (LMIA) is a document that an employer in Canada may need to get before hiring a foreign worker (IRCC, n.d.). After a period of 3,900 hours of employment within 22 months and a maximum of four years, live-in caregivers can apply for permanent residency (Salami., \& Nelson., 2014, p. 155). It is important to note that the LCP is a temporary work program that has come to be understood as a way for Filipinx migrants to obtain permanent residency in Canada.

Migrant domestic care workers are increasingly in demand as caregivers for older adults in several countries of the developed world, including the United States, Canada, the United Kingdom and Ireland. This demand is largely driven by the aging population, the diminishing state provision of care services, as well as the incorporation of women into the labor force without policies in place to reconcile the demands of family life (such as childcare) and work.

(Salami., \& Nelson., 2013, p. 154).

Rather than creating a nationwide care program, Canada thought that it would be economically feasible for the Canadian government to continue to rely on temporary migrant workers. This cheap yet skilled labour of migrant women is integral to meet the Canadian settler 
colonial state's capital interests. Foreign, temporary, and cheap labour have extensively benefited Canada's neoliberalist apparatus. Farrales (2017) borrows Pauline Barber's idea of a “continuing dance of flexibility and capital mobility to understand the gendered class subjectivities in Philippines-Canada migration." Barber adds that "labor export in the Philippines fits perfectly with the cheap labor demands of Canada that the state meets through immigration and labor programmes" (p. 209). Building on this, Hari (2014) states that it is clear that temporary foreign worker programs play a key role in meeting this goal due to the privileged forms of temporariness that Canada offers (p. 37). Thus, we can start to see how migrant workers continue to be de-skilled and dehumanized through the LCP and that live-in caregivers are favored for their temporary status and cost-effectiveness. It is hard to talk about Canada's care sector without mentioning the damage that they have done to Filipinx caregivers because, as discussed in the remainder of this chapter, the LCP has gone through many versions since 1992. Most of the scholars cited in this section and I would agree that none of these versions helped protect migrant caregivers and instead, what these versions represent are various pathways of perpetuating and maintaining temporariness.

\section{Deskilling Filipinx migrants}

Filipinx care workers were expected to be complacent amidst unpleasant working conditions if they ever wanted to bring their own children to Canada. The requirements of the program made it difficult to earn additional income because the 'live-in' component of the program opened the doors to further exploitation by the employer of the migrant caregiver. Moreover, upon completion of the two-year work requirement, migrant caregivers were left unaware of how to navigate life in Canada after becoming permanent residents. Pratt (2012) makes a strong connection between 
deskilling and family separation; she states that many women have few resources after completing the program because they are sending large sums of money they earned to their families in the Philippines, while also attempting to save money to bring their families to Canada (p. 16). Pratt (2012) adds: "the importation of women from the Global South under conditions of indentured servitude to care for Canadian children, seniors, and the disabled can be read as an instance of sovereign power, whereby Filipino women are sacrificed for the vitality of the Canadian population" (p. 3).

Not only is this perspective reflected through the LCP, it is also endorsed by the Philippine government. In 1998, President Corazon Aquino titled overseas Filipino workers as "the new economic" or "modern day heroes" - as echoed by past presidents such as Gloria Macapagal Arroyo who advertised the Philippines as "Home of the Great Filipino Worker" which then put the responsibility onto the Flipinx migrant workers to build back the country's economy and promote a positive image of the Philippines (Pratt, 2012, p. 10). The 1992 version of the LCP put migrant workers in situations where they were expected to tolerate low wages, lack of governmental support, and precarious legal status. The LCP and the phases that it has gone through, which I outline below, speak to the economic disparities between states due to the Global North's financial access and Global South's limited resources; thus, creating a 'care deficit' and simultaneously a 'care drain' in Global South countries (Tungohan \& Hanley., 2019, p. 225).

\section{The 2014 Caregiver Program (CP)}

The live-in component of the LCP was lifted in 2014 by the federal government in their efforts to resolve issues relating to unpaid overtime, poor working conditions, and other issues that were 
brought forth by advocacy groups supported by LCP participants (Canadian Immigration Law Firm, 2017). The government also tried to process permanent residence applications within six months, thus reducing the wait times for family reunification significantly. Employers were now expected to pay caregivers a presumably "live-able" wage according to their work location (Drolet, 2016, p. 2). Most significant of these changes was the roll-back of the direct pathway to permanent residency previously available under the 1992 version of the program.

Despite the supposed improvements to the living and working conditions of workers, the 2014 Caregiver Program simultaneously increased the vulnerability of migrant workers by creating less certain routes to permanent residency. The federal government replaced the original program with two separate streams/classes: caring for children and caring for people with high medical needs. Additionally, the option of applying for permanent residence with 3,900 hours after 22 months was also removed, which meant that faster program completion was no longer an option (Drolet, 2016, p. 2). Although the federal government made these changes, it still did not protect caregivers from abuse, which remained a primary concern for advocates and workers. Rather, the CP introduced new language and licensing requirements for permanent residency applications, along with a quota for how many permanent residency spots are given per year (Banerjee., et al, 2017, p. 8).

Under the 2014 revision to the program, workers may be eligible to apply for permanent residence under the Caring for Children Program if they meet the following requirements (Canadian Immigration Law Firm, 2017): 
1. At least 24 months of full time ( 30 hours/week) work experience in Canada as a home child care provider (National Occupational Classification (NOC) 4411) in the four years before you apply

2. Score at least Canadian Language Benchmark (CLB) 5 in an approved language test within the two years before you apply

3. A Canadian post-secondary degree, diploma, or certificate with a minimum duration of one year, OR a foreign degree, diploma, or certificate and an Educational Credential Assessment (ECA) demonstrating it is equal to a Canadian one-year post-secondary degree

Similarly, workers are eligible to apply for permanent residence under the Caring for People with High Medical Needs Program if they meet the following requirements:

1. At least 24 months of full-time (30 hours/week) work experience in Canada in one of the following occupations: Registered nurses and registered psychiatric nurses (NOC 3012), Licensed practical nurses (NOC 3233), Nurse aides, orderlies and patient service associated (NOC 3413), Home support workers and related occupations (NOC 4412). An important exclusion is that Housekeepers are not eligible under 4412, making job titles an important distinction.

2. If work experience is in NOC 3012, the applicant must score at least Canadian Language Benchmark (CLB) 7 in an approved language test

3. If work experience is in NOC 3233, NOC 3413, or NOC 4412, applicants must score at least Canadian Language Benchmark (CLB) 5 in an approved language test 
4. A Canadian post-secondary education degree, diploma, or certificate of at least one year OR a foreign degree, diploma, or certificate and an Educational Credential Assessment (ECA) demonstrating it is equal to a Canadian one-year post-secondary degree.

In the shift from the $1992 \mathrm{LCP}$ to the $2014 \mathrm{CP}$, there is an increase in requirements for higher education and language proficiency. There are also specific occupational classifications (NOC) that must be met, making job titles and categories restrictive and significant to be eligible. Additionally, caregivers under the CP had to undergo a medical examination with their application and another one later in order to receive permanent residence, adding procedural requirements and undue expenses. The Federal government argued that these additional medical requirements were put in place to ensure that migrant caregivers were not overwhelming Canadian health services, which can be argued against on humanitarian and ethical grounds alone. In 2010, the second medical examination requirement was ruled out under the Juana Tejada Law. The law was named after a caregiver named Juana Tejada who was diagnosed with cancer and passed away while working in Canada (Drolet, 2016, p. 3). It is thanks to caregivers and their advocates that this and many other changes towards increased rights and entitlements of migrant caregivers were made possible.

\section{Care Pilot}

In 2019, Immigration, Refugees, and Citizenship Canada (IRCC) introduced another five-year pilot program, changing once again the requirements under the 2014 Caregiver Program, which 
was intended to allow for more flexibility for migrant caregivers. The main change was that it allowed migrant caregivers to come to Canada with their immediate family members (IRCC, n.d.). This pilot program also replaced the 2014 split streams: Caring for Children and Caring for People with High Medical Needs. In place of specific occupational categories, the program allowed:

1. Occupation-specific work permits for caregivers, which provides them with flexibility and opportunity change jobs quickly while remaining in the same occupational category, when necessary

2. Open work permits for spouses/common-law partners and study permits for dependent children, to allow the caregiver's family to accompany them to Canada with legal status

Despite the flexibility of occupation-specific permits, applicants must continue meet the higher education and language requirements (IRCC, n.d.):

1. Have a job offer in Canada at the time of application for a work permit

2. Achieved CLB 5 in an eligible language test

3. Accrue one year of Canadian post-secondary (or higher) education for applicants in Canada; or equivalent foreign educational credentials based on an Educational Credential Assessment (ECA) report issued by an organization assigned by IRCC

At face value, these changes to the program requirements appear to have come a long way since 1992. The removal of the live-in requirement and provisions for occupational specific permits rather than relying on one employer may seem progressive. These are steps in the right 
direction but came at the price of further restrictions. The $2014 \mathrm{CP}$ and most current 2019 pilot program have greater educational, language, and institutional requirements to meet the eligibility criteria for permanent residence. As noted, both versions require at least one more year of postsecondary education (Canadian or foreign equivalent) in comparison to the 1992 LCP's requirement of a Canadian-equivalent high school diploma. The language requirements are still CLB 5, which is more specific than the 1992 requirement of "good knowledge" of official languages. Oddly enough, the higher language requirement of CLB level 5 for English or French exceeds the language requirement for proof for citizenship, which is CLB level 4 (IRCC, n.d.). It would seem that program participants need a higher level of language proficiency to apply for landed status than when applying for citizenship once they acquire landed status. Moreover, although the 2019 pilot program does allow for open work permits for spouses or common-law partners and study permits for dependent children, it is not clear whether or not the students will be paying international student fees.

In addition to these procedural changes, and maybe more importantly, the IRCC did nothing to ensure that family members can successfully settle in Canada. There are no further provisions than legal permits; there is no social assistance or other resources to help program participants find affordable housing, healthcare, and other necessities of living in Canada. Furthermore, the government is still delaying permanent residence by not granting landed status upon arrival. 


\section{Interim Pathway}

In 2019, a new pathway was created because many caregivers discovered that they did not qualify for permanent residence if they arrived under the 2014 Caregiver Pilot. This three-month interim pathway was the Canadian government's effort to provide caregivers with the chance to migrate to Canada permanently. To be eligible for this pathway, caregivers must meet the following requirements (IRCC, n.d.):

1. Must have had valid work permit or have applied to extend their work permit and be awaiting a decision, or have applied to restore status as a worker

2. Must have gained at least 12 months of full-time work experience since the launch of the 2014 Caregiver Program

3. Meet CLB Level 5

4. Must have a Canadian high school diploma or equivalent non-Canadian educational diploma

Despite their efforts, this transition did not serve to benefit many caregivers. As migrant rights organizations reported, many foreign care workers reached out and expressed their concern within a week of the announcement of this pathway identifying its restrictive circumstances. Some caregivers completed the 12-month work requirement but they were still unable to acquire work permits due to the small-time frame; this pathway was open from March to June of 2019 only (The Migrant Workers Alliance for Change, 2019). The 2019 Interim Pathway is the current iteration of the LCP. Through the various phases that this program has undergone, it may seem as though 
the Canadian government has tried to make significant changes; however, migrant caregivers continue to negotiate highly restrictive requirements and exclusions from eligibility. Though significant changes have been made to the original program, the main issue has yet to be resolved: Canada's legal systems continue to maintain migrants' temporariness and delay conferring permanent status and its associated rights.

The Philippines and Canada have a long-standing labor export-import relationship. The Philippines government still fails to adequately support and protect Filipinx domestic workers, which then allows countries like Canada to further perpetuate temporariness and deny foreign workers important rights and entitlements. Canada does not readily offer the privilege of permanence for those categorized as "low-skilled" (p. 37) because "permanent residency is more readily available to socially desirable migrants, such as those with 'high skills', while permanent temporariness is a characteristic of 'less desirable' migrants, such as those with 'low skills' (Rajkumar et al., 2012, p. 505). From the 1992 Live-in Caregiver program, to its most current iteration which is the 2019 Care Pilot and Interim Pathway, not much has changed in regard to protecting migrant workers and changing the conditions of temporariness that persist in the form of exclusionary policies and practices to restrict access to landed status and its entitlements to family reunification and social welfare. Therefore, I echo Rupa Banerjee, Philip Kelly, and Ethel Tungohan recommendation informed by surveys and focus group discussions with Filipina women who arrived as caregivers through the various versions of this program: give all caregivers landed status upon arrival (Banerjee, et al., 2017, p. 29). 


\section{WRITING MYSELF INTO THEORY - CHILDHOOD AS A LIFETIME EXPERIENCE}

Let me begin by saying that I came to theory because I was hurting - the pain within me was so intense that I could not go on living. I came to theory desperate, wanting to comprehend - to grasp what was happening around and within me. Most importantly, I wanted to make the hurt go away. I saw in theory then a location for healing - bell hooks, Theory as Liberatory Practice.

In deciding on the theoretical framework for my thesis, I found that I, a sponsored dependent of a former Live-In Caregiver Program (LCP) participant, am missing from normative theories of childhood and child development. Our narratives are excluded because it speaks to the ongoing forms of colonialism in the Philippines. Hannah Dyer in her book The Queer Aesthetics of Childhood: Asymmetries of Innocence and Cultural Politics of Child Development (2020) includes Jonathan Hobin's series "In the playroom". This series includes portraits of children who were cast as actors to be photographed in scenes of geopolitical conflict to showcase how global issues bleed into children's play; which is often depicted as being on a playground, bedrooms, and kitchen (p. 36). Dyer (2020) uses Hobin's series to illustrate non-normative childhoods because, as she argues, the children are not given the same amount of protection as others under these different circumstances informed by global issues. I would argue that the ways in which the LCP further perpetuated family separation, simultaneously added layers of complexity to Western understandings of the nuclear family, childhood innocence, and caring practices. I soon realized that LCP childhoods were integral to critiquing normative models of childhood and child development.

As I write myself into theory, I am finding myself stumped and unable to articulate why I am drawn to three particular concepts to achieve my goal of separating a theoretical space for the LCP: Ethel Tungohan's (2012) transnational hyper-maternalism, Hannah Dyer's (2020) framing 
of childhood innocence, and Valerie Francisco-Mechavez (2018) concept of multidirectional care. Am I stumped because these theories emulate my childhood? Am I stumped because these theories provide me with the language to name, and label my experiences? Or is it because these theories combined talk about a reality that I experienced and therefore I cannot think of it as merely a concept, as it might be for some. Rather, it is my reality. It may be the latter, or it could be all. But one thing I know for sure is that the entirety of this thesis advocates for rethinking "childhood," because it is not a thing of the past. Rather, childhood is a formative phase in our life where experiences that we have, and the affective traces they leave, linger throughout our lifetime.

Ethel Tungohan's concept of transnational hyper-maternalism (2012) explains the ways that Filipino mothers who left their families in the Philippines to become caretakers overseas, overcome accusations of neglect due to their ability to 'mother across borders' (p. 39). Hannah Dyer's articulation of childhood innocence builds on Tungohan's (2012) theorizations of transnational motherhood by including the complex ways some children are withheld from the benefits of innocence due to interplay race, class, gender, sexuality, coloniality, and globalization. In this chapter, I also argue that at the heart of transnational hyper-maternalism and childhood innocence is Valerie Francisco-Menchavez's conceptualization of multidirectional care, which helps us see the multitude of ways that transnational family members redefine care work in the family. 


\section{Transnational hyper-maternalism: Overcoming accusations of maternal neglect}

My twenty-third birthday card from mom:

My Caregiver Story ( by: Rita J.) Inbox $x$

Rita Ramos <ramosr93@yahoo.com>

to me, Aa- -

I came here through Caregiver Program? Why did I come here? One is to give a good future for my child and to avail all the good programs that Canada offers once you become a Canadian Citizen. In the Philippines, to get an education, you must have to have lots of money specially if you're going to university, masters and doctorate, must have to be rich. In the Philippines if you're sick and you have no money, the hospital won't entertain you, no health benefits like what Canada offers. I came here not for myself but for my child's future. Yes, I admit, I felt so bad leaving my child behind but I closed my eyes and took my chances in this foreign land. Being away from my child, I was not able to give the attention and love that she needs, yes it's not all about money, but if you look around and see how hard life back home, you will sacrifice and just hope and pray that one day your child will understand why you did this.

I came here October 10, 1999. By this time Caregivers were treated nicely, if it's you're first and second year, you must have to live with your employer, they call it Live-in caregiver, the employer will provide you your own room, food and of course a salary as their nanny. So far, for the two employers I had, I was treated very good, they treated me like a part of their family, even when it's time to bring my daughter here, they helped me by providing a letter to the immigration that they take the full responsibility to me and my daughter. There are so many programs offered by the government for new comers, they're are agencies where you can go and ask for help. Most immigrants uses Caregiver program as a stepping stone to reach what they wanted in life. Some caregivers, they just don't want to upgrade, scared to ask or come out to their comfort zone. Some are ambitious and find a way to do what they're supposed to do. I was a teacher in the Philippines, so after my two years under caregiver program and finally got my open permit, I applied right away as a teacher in one of the private schools here and luckily, I got the job. But as a single mother, I must have to juggle. Teacher during weekdays and cleaning lady in the weekends just to have a decent place to live, a car to drive around, pay bills and food. My money is just good enough, sometimes not. The things that I missed, is my child's childhood, I'm not there for her most of the time. I missed her games and shows but I know I am raising a tough, smart and independent little girl, I want her to grow like that. I don't want her to be weak, because life is not easy, it's very complicated. In life, you must have to be mentally and emotionally strong, because if not, you'll go crazy. I'm so sorry to my child if she felt she's unloved, but honestly, I love my child so much that I was able to swallow my pride, from school principal (in the Philippines ) to being a nanny, I used a lot of tears and sweat to get where I am now. I am not rich yet, still have lots of debts, but watching my daughter grow as a strong and smart woman makes me feel so rich and proud. Thank you to Fernando, who helped me and for still helping me. Thank you for being always there for me and my daughter.

I just hope that some children will understand the reason why we sacrificed them over other children, well, that's our job and that job makes us support our family. About the treatment with caregivers, so far that year 1999, everything is different, nannies were given all the privileges that a Canadian under working permit will get. They let us stay here until we become Canadian citizens, offering all these education funding to our children so they can go to school and get their education. Here in Canada, even if you are poor, you can go to school, in the Philippines, no money no honey.

My take, I am happy that I came here. My daughter now is a university graduate, she's taking her masters and planning to take her doctorate, yes she's self supporting now but with the Canadian government education program's help.

To my child, I am so sorry for leaving you behind. You're already seven years old when we finally met and get to know each other but still mother needs to work seven days a week just to make ends meet. Yes, I sacrifice a lot, but watching my daughter now, as if I won a lottery.

To my daughter, keep up the good work, I love you very much and I am so proud of you $;$

"I came here through the Caregiver Program? Why did I come here? One is to give a good future for my child and to avail all the good programs that Canada offers once you become a Canadian Citizen. In the Philippines, to get an education, you must have lots of money specially if you're going to university, masters and doctorate, must have to be rich. In the Philippines if you're sick and you have no money, the hospital won't entertain you, no health benefits like what Canada offers. I came here not for myself but for my child's future. Yes, I admit, I felt so bad leaving my child behind but I closed my eyes and took my chances in this foreign land.

Being away from my child, I was not able to give the attention and love that she needs, yes its not all about money, but if you look around and see how hard life back home, you will sacrifice and just hope and pray that one day your child will understand why you did this.

I came here October 10, 1999. By this time Caregivers were treated nicely, if it's you're first and second year, you must have to live with your employer, they call it Live-in caregiver, the employer will provide you your own room, food and of course a salary as their nanny. So far, for the two employers I had, I was treated very good, they treated me like a part of their family, even when it's time to bring my daughter here, they helped me by providing a letter to the immigration that 
they take the full responsibility to me and my daughter. There are so many programs offered by the government for new comers, they're are agencies where you can go and ask for help. Most immigrants uses Caregiver program as a stepping stone to reach what they wanted in life. Some caregivers, they just don't want to upgrade, scared to ask or come out to their comfort zone. Some are ambitious and find a way to do what they're supposed to do. I was a teacher in the Philippines, so after my two years under caregiver program and finally got my open permit, I applied right away as a teacher in one of the private schools here and luckily, I got the job. But as a single mother, I must have to juggle. Teacher during weekdays and cleaning lady in the weekends just to have a decent place to live, a car to drive around, pay bills and food. My money is just good enough, sometimes not. The things that I missed, is my child's childhood, I'm not there for her most of the time. I missed her games and shows but I know I am raising a tough, smart and independent little girl, I want her to grow like that. I don't want her to be weak, because life is not easy, it's very complicated. In life, you must have to be mentally and emotionally strong, because if not, you'll go crazy. I'm so sorry to my child if she felt she's unloved, but honestly, I love my child so much that I was able to swallow my pride, from school principal (in the Philippines ) to being a nanny, I used a lot of tears and sweat to get where I am now. I am not rich yet, still have lots of debts, but watching my daughter grow as a strong and smart woman makes me feel so rich and proud. Thank you to Fernando, who helped me and for still helping me. Thank you for being always there for me and my daughter.

I just hope that some children will understand the reason why we sacrificed them over other children, well, that's our job and that job makes us support our family.

About the treatment with caregivers, so far that year 1999, everything is different, nannies were given all the privileges that a Canadian under working permit will get. They let us stay here until we become Canadian citizens, offering all these education funding to our children so they can go to school and get their education. Here in Canada, even if you are poor, you can go to school, in the Philippines, no money no honey.

My take, I am happy that I came here. My daughter now is a university graduate, she's taking her masters and planning to take her doctorate, yes she's self supporting now but with the Canadian government education program's help.

To my child, I am so sorry for leaving you behind. You're already seven years old when we finally met and get to know each other but still mother needs to work seven days a week just to make ends meet. Yes, I sacrifice a lot, but watching my daughter now, as if I won a lottery.

To my daughter, keep up the good work, I love you very much and I am so proud of you"

"My twenty-third birthday card from mom" (included above as a photograph and the text below) is an email that I received from my mom a day before my birthday, and after a phone call with her about this project. When I woke up the next day, I checked the notifications on my phone, and I read "My Caregiver Story". Before I could even read the entirety of the email, I remember 
suddenly feeling a heavy weight on my chest and I started to cry. My twenty-third birthday was marked by emotional turbulence, often getting hit with waves of sadness and regret, then a sense of calm and peace. I kept asking myself "is this worth it?" "why would I open up old wounds if my mom and I are on good terms now?". Then, I started to think about if we were ever on good terms because the seemingly old wound still felt fresh for me. Sort of a scab that you keep picking at, and therefore never heals.

The start of this project was my own selfish desire to figure out why I feel so strongly about children whose childhoods are left out of normative theories of childhood and child development. I felt this most deeply when I was working as a teaching assistant for a kindergarten class in Markham, Ontario. As I was reading books, playing, and learning with my students, I started to think about whether or not I wanted kids. One thing I knew for sure was that I wanted to be the type of mother that my mom was not able to be for me. Through rigorous self-reflection however, I realized that my mom chose to go to work rather than watch me play a sports game so that she can pay the bills at the end of the month, and her choosing to come to Canada for a chance at a better life was not her being selfish. Rather, what my mom did was a selfless act. Childhoods like mine were not represented in the children's books I read to my students, and it made me feel that talking about my upbringing was taboo. My process of self-discovery serves a larger ideological question; it is my contribution to re-thinking childhood as not a thing of the past, but rather a lingering affect that is always with us. Although some parts of this thesis rely heavily on ongoing practices of feminist reflexivity, I remind myself that discomfort is a small price to pay for growth.

Canada is defined by its identity as a nation of immigrants. Most of them are from Asia, with the three leading countries in 2011 being the Philippines, China, and India. Thus 91.1\% of the Canadian population comes from racialized groups and three-quarters of them are immigrants 
(Nichols \& Tyyskä, 2018, p. 608). The gender imbalance makes the total percentage of $91.1 \%$ more stark as women have outnumbered men as migrants. Before the acknowledgement and growth of women's contribution to the paid labor force, the general Western construction of the family unit required a man to be the sole breadwinner and the women were left in charge of childbearing and housework. As women entered the paid labor force in the Global North, the restructuring of the Western gender-based distribution of domestic labor became necessary though did not occur (Labadie-Jackson, 2008, p. 69). Women found themselves in the paid labor force, while simultaneously still being responsible for childbearing and housework. In the late 1960s and 1970s, second-wave feminist movements started to occur which increased the numbers of white, middle-class women who were able to pursue careers, and led to an increasing need for new childcare opportunities the were cheap and widely available.

Canada has a long history of using foreign domestic workers to meet its social reproductive needs. The Foreign Domestics Movements (FDM) was established in 1981, which meant that white, middle class women were able to continue pursuing careers in the paid labor force while they hired migrant domestic workers to bear child rearing and household responsibilities, predominantly from the Philippines (Tungohan, 2012, p. 43). Ethel Tungohan developed the concept of transnational hyper-maternalism to describe the complex realities that Filipina labor migrants face as they are unconsciously expected to provide for their families back home, while also fulfilling their maternal responsibilities for their children in the Philippines (Tungohan, 2012, p. 39). Tungohan portrays the lived realities of Filipina migrant workers as they work towards permanent residency and the possible reward of family reunification. Filipina migrant workers are stuck in this limbo of caregiving for their employer's children in Canada and caregiving for their own children in the Philippines at a distance. 
Tungohan (2012) makes it clear that everyone is affected, although when Filipina caregivers were asked if they regretted their decision to leave their children, they would deny it because they understood that their families would have fared worse without their support (p. 45). Tungohan (2012) also sheds light on how children of migrant mothers feel that they have been abandoned, but are able to cope with their mother's absence through regular communication. Nonetheless, it is difficult to definitively show that children of migrant mothers' fare worse (Tungohan, 2012, p. 48). In the thesis, I include the words of Filipinx youths alongside my personal anecdotes, and use them in conversation, as my participants and I are adults who are reflecting on our experiences as children who were sponsored for permanent residency to Canada by their mothers, who were former participants of the LCP. In their stories, these young adults like me, who are reflecting back on their childhood, uncover past traumas and family histories, and most importantly they demonstrate how innocence is not static but an ongoing and dynamic experience.

My mom's letter to me exemplifies the concept of transnational hyper-maternalism. In my mother's words:

"In the Philippines, to get an education, you must have to have lots of money specially if you're going to university, masters and doctorate, you must have to be rich. In the Philippines if you're sick and you have no money, the hospital won't entertain you, no health benefits like what Canada offers. I came here not for myself but for my child's future. Yes, I admit, I felt so bad leaving my child behind but I closed my eyes and took my chances in this foreign land. Being away from my child, I was not able to give the attention and love that she needs, yes it's not all about money, but if you look around and see how hard life is back home, you will sacrifice and just hope and pray that one day your child will understand why you did this"

"As a single mother, I must have to juggle. Teacher during the weekdays and cleaning lady in the weekends just to have a decent place to live, a car to drive around, pay bills and food. My money is just good enough, sometimes not. The things that I missed, is my child's childhood. I'm not there for her most of the time. I missed her games and shows but I know that I am raising a tough, smart and independent little girl, I want her to grow like that. I don't want her to be weak, because life is not easy, it is very complicated. In life, you must have to be mentally and emotionally strong, because if not, you'll go crazy." 
"But honestly, I love my child so much that I was able to swallow my pride, from school principal in the Philippines to being a nanny... I just hope that some children will understand the reason why we scarified them over other children, well, that's our job and that job makes us support our family"

These quotes echo Tungohan's (2012) participants' responses, as three Filipina caregivers conclude that self-sufficiency and independence were key to survival, and were transmitted intergenerationally and ingrained in their children (p. 51). Transnational hyper-maternalism allows women migrant workers to overcome accusations of maternal neglect, while at the same time contributing to the larger narrative of the "superior mother" - which understands and expects that once a woman becomes a mother, she is looked at, and feels the societal pressure to be the "perfect" mother. These internalized assumptions of perfectionism affected me as a child and even now as an adult. If interrogated, we can start to see how this culture of perfectionism in related to familial roles and the expectation that children will be "successful". This expectation and its burden is not captured in normative theories of childhood development. The cyclical system of cheap migrant women's labor that aids in the success of white, upper- to middle-class women and their families in the West plays a critical role in perpetuating intergenerational expectations of "perfectionism." I view this project as illuminating my own life but also an opening for affective landscapes to encourage children of transnational families to uncover their repressed and difficult memories in order to move towards a hopeful feeling that reassures them that there are other ways of living. 


\section{Childhood Innocence}

Sometimes, the 'other ways of living' involve simply being seen as a human being. The work of Jamaican artist Ebony G. Patterson, whose installation can be found in the Studio Museum in Harlem, exemplifies this vision. Her installation consists of a Pepto-Bismol-colored child's room that has toys for kids of all ages and photographic works capturing multiple kids, all dark-skinned amongst a "whimsical sea of pattern and texture" (Felsenthal, 2016). In a 2016 Vogue interview regarding her installation, Patterson speaks about what happens to children who are not protected by perceived innocence. Her interview responses clarify the ways in which the concept of childhood innocence further perpetuates white supremacy (Dyer 2020; Robinson 2012; Garlen 2019).

"I wanted the audience to think not about the names we are already aware of, but to think about children of color in general"

"We somehow seem to deny these children the same sense of innocence that any other child would be afforded, as if somehow they're different [...] because of their blackness, they're not allowed the possibility of humanity"

(Felsenthal, 2016)

Before the Enlightenment, children in the West were seen as already having sinned because "the devil has been with them already," in the words of Cotton Mather, a Puritan minister in 1689 who painted the image of babies "going astray as soon as they are born" (Bernstein, 2017). It was not only Mather who thought this way, but many powerful leaders such as Benjamin Wadsworth who said children are "sharers in the guilt of Adam." John Locke, thought that children were blank slates, Jean-Jacques Rousseau, imagined children as connected to nature, and poet William 
Wordsworth believed that children were holy innocents that could lead adults to God (Bernstein, 2017). As this history shows, the ideals of children and childhoods are constantly re-defined and re-interpreted. Childhood innocence emerged as a social practice in the U.S in the $19^{\text {th }}$ century which marked what an American childhood ought to be - and that is white and on the path to godliness.

In a 2017 New York Times article titled Let Black Kids Just Be Kids, Robin Bernstein conducts a deep historical dive into the ideological lineage of childhood innocence. The following quotations from the article explain the ways in which childhood innocence is embedded with racial and colonial underpinnings; Bernstein also gives us an alternative worldview by demanding a shift in language that reinforces justice over innocence.

"The problem, however, is that every time we insist that the gates of innocence open to children of color, we limit ourselves by language, a "frame," as the linguist George Lakoff would say, that is embedded in racism. When we argue that black and brown children are as innocent as white children, and we must, we assume that childhood innocence: It's part of a 200-year-old history of white supremacy"

"It is time to create a language that values justice over innocence. The most important question we can ask about children may not be whether they are inherently innocent. Instead: Are they hungry? Do they have adequate health care? Are they free from police brutality? Are they threatened by a poisoned and volatile environment? Are they growing up in a securely democratic nation?"

(Bernstein, 2017)

I agree with Bernstein that we need to create a new language that helps us see children not as innocent, but as human beings. Dyer's (2020) iteration of childhood innocence helps us come up with this language, as she believes that aesthetic expressions of childhood illustrated by children give us insight into creative resistances against normalcy (Dyer, 2020, p. 4). 
Being inspired by Dyer's aesthetic approach towards childhood innocence, I asked my participants to share an object that best represents their childhood. These aesthetic approaches help give voice to the non-verbal, the tacit, and the material properties of things (Woodward, 2016, p. 360). Below are the images that narrate the painful love that is caused by family separation, and children whose childhoods are informed by racism, migration, and economic uncertainty.

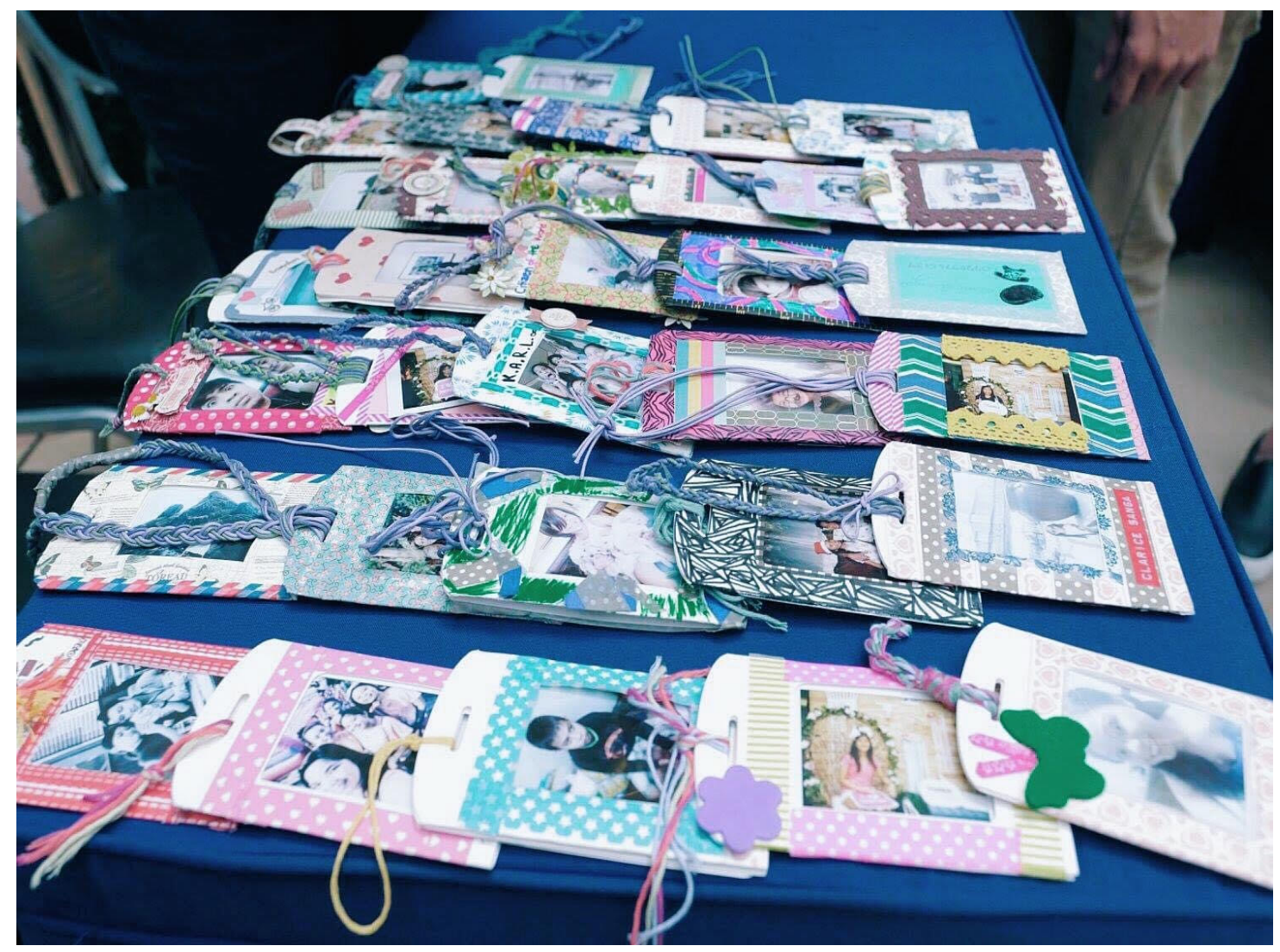

"Back in the Philippines, they also have this event called instax and crafts and they tell you a craft to make and they choose which one is the best. I won two times and I won two instax at one time. I gave them to my cousins. We had to make ornaments - the ones you hang on the Christmas tree and the other one is a luggage tag." 


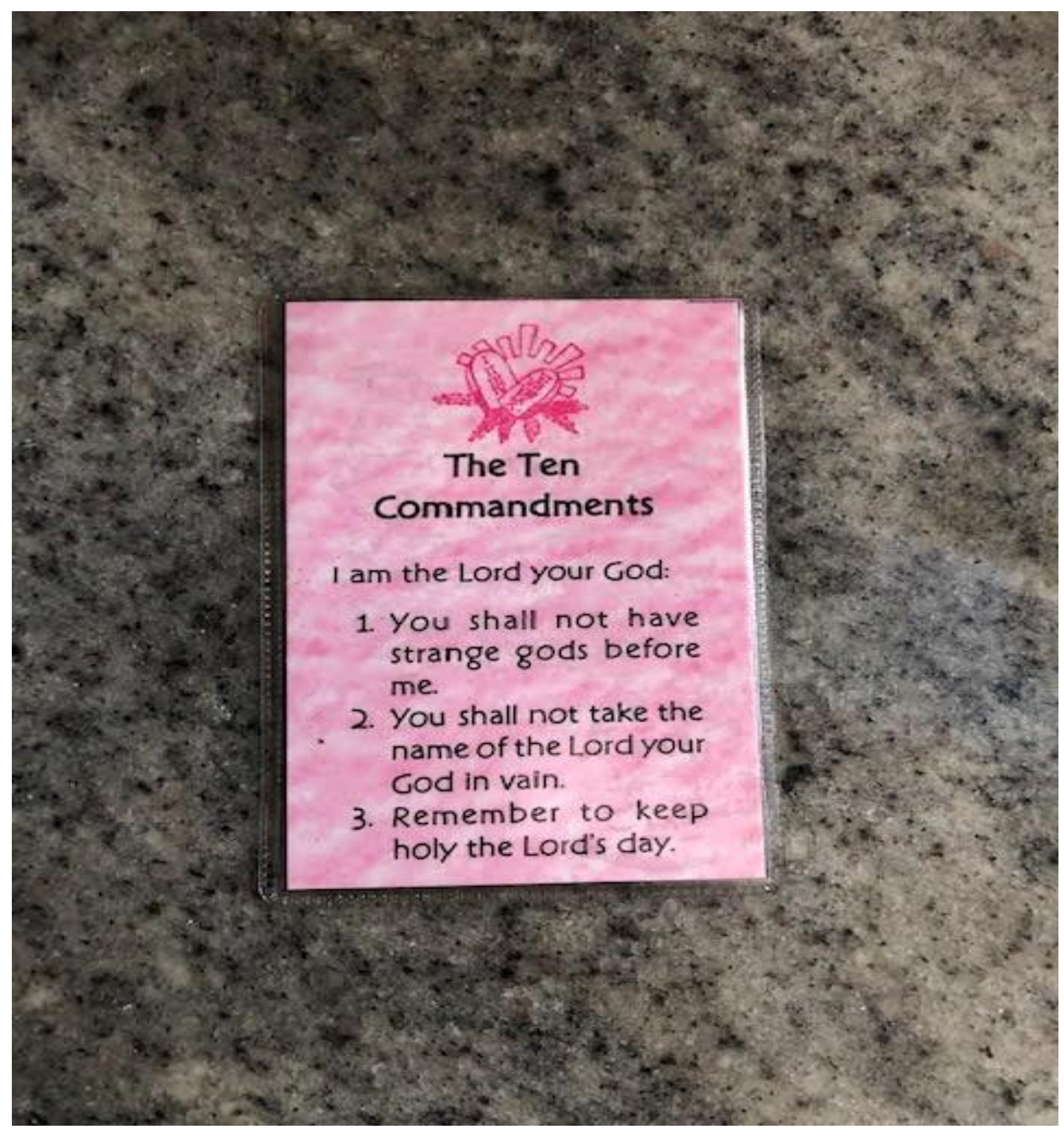

"I grew up Catholic and my mom left my brother and I at a convent when she migrated to Chicago. My experience growing up with nuns was positive. They knew I was gay and not once did they ever judge me for it. They told me counternarratives against homophobia. I remember them saying that being gay is not a skin and that God loves me. They also came to visit us here in Canada back in 2012. Although I am no longer practicing Catholic, I still consider some of their teachings important, especially the 'do no harm' principle which aligns with my idea of feminism" 


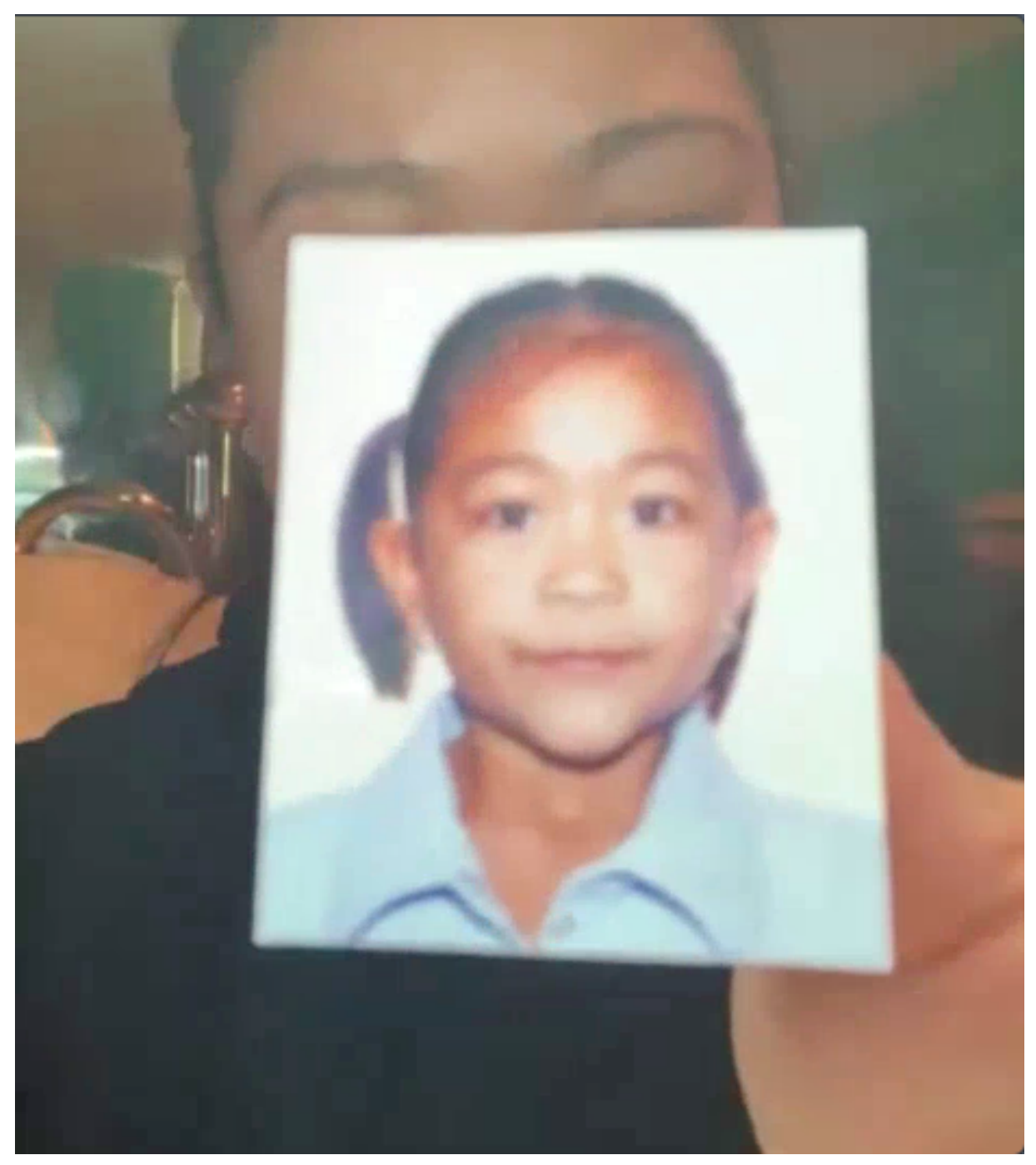

"This is the picture that the immigration office took of me for my passport when I had received my citizenship. I remember being at the immigration board when we had to go into this room and take a picture of me. I had to sign a few things when I was really young and this was the first picture of me in Canada which is why I am using it as my item."

The participants in this project were children, like me, who have experienced family separation and were born in a place where histories of colonialism extend into the future. Items such as photographs of family members, religious beliefs, and passports are the objects that they shared with me that best represent their upbringing. I interpret these images as aesthetic resistances against normalcy. These objects were brought by children from transnational families, which acted 
as a stepping-stone for them to narrate their childhoods, that were spent creating luggage tags with pictures of your family members on it because you were preparing to move. Carrying around a pocket size image of The Ten Commandments because no parental figure was around to give you wisdom, and cherishing your passport photo because it reminds of you the times you spent in government offices. Waiting in lines, and getting questioned by immigration officers to hopefully walk out of the building with a Canadian passport in hand, and hear a sigh of relief from your caregivers who helped made it all possible.

Moreover, these memorable objects also add another layer of narrative when we consider the people who partook in the caring strategies that were needed in order to help make the family function in the absence of the maternal figure. Francisco-Menchavez (2018) explains this perfectly: "Families left behind continue without that one person who migrated, and production of life in the place left behind is ongoing: Children have to be sent to school, bills need to be paid, and dinners need to be cooked." (p. 10). Below is an exploration of Franciso-Menchavez's iteration of multidirectional-care, and how it is at the center of both transnational hyper-maternalism, and childhoods that were not protected by perceived innocence.

\section{Multidirectional Care}

At the heart of this thesis is the concept of multidirectional care, which describes the ways in which transnational family members use, and activate multiple resources, people, and networks that redefine care work in the family (Francisco-menchavez, 2018, p. 10) Most importantly, Francisco-Menchavez describes emotions as "transnational affect" and uses it to challenge things that seem "natural" (Francisco-Menchavez, 2018, p. 9). I echo this approach to understand care 
performed among transnational family members, as I interview young adults who were sponsored for permanent residency in Canada by former participants of the LCP. The images that I highlight above not only add to ongoing conversations about childhood innocence, but they are also representative of multidirectional care because the images act as a lingering affect that can be traced back to the one person who migrated and the multiple roles played by guardians, family members, and various members of the community who made it possible. "Multidirectional care considers the transnational practices of care and labor enacted by all members involved in transnational arrangements and how they make meaning of those practices (Francisco-Menchavez, 2018, p. 10). 'Making meaning' can manifest itself in objects such as a family photo, a religious symbol like the Ten Commandments, and it can also be a passport photo. These objects signify a 'then' and 'now' for families who were separated by migration and the transnational caregiving practices that strengthened their diasporic ties.

"The unpaid and more intimate dimensions of transnational lives, in particular of 'kin-work' and caregiving, are often overlooked altogether, and their role in the more 'public' political economy of migration and diaspora is regularly undervalued. An analysis of transnational care circulation makes evident the links and intersections between kinship and economic and political motivations in migratory moves, highlighting the role of family and the domestic sphere in sustaining diaspora ties"

(Baldassar \& Merla, 2013, p. 8)

Throughout this thesis, you will notice the ways in which multidirectional care is practiced within the three families that you will encounter. The 'kin-work' strategies that the families operate are bonded by obligation, love, and trust. The flow of care is far from harmonious and it is to be expected that the caring strategies are constantly being negotiated by family members (Baldassar \& Merla, 2013, p. 7) Baldassar and Merla (2013) use Wellman's 1988 theory of network ties, 
which is defined as "asymmetrically reciprocal, differing in content and intensity', including between close relationships characterized by strong ties. How Baldassar and Merla interpret this is what Wellman warns against, mainly treating all units as if they had the same resources, and all times as if they were symmetrical (p. 8). To put it another way, through a Western lens of equal reciprocity and perceived protection, it is easy to label mothers who left their families to pursue work as 'bad mothers', it is easy to label children who are 'street-smart' as 'bad children', and it is easy to cast judgement to an adoption that happened within the family. Throughout this thesis, I challenge and work to replace Western understandings of family and care, as I use concepts such as transnational-hyper maternalism, childhood innocence, and multidirectional care to help make sense of the complexity intrinsic to families separated by migration. I use these concepts in my attempt to write family, childhoods, and belonging that are wrought under capitalism and globalization into normative theories of migration, diaspora, displacement, and child development. 


\section{AM THEM AND THEY ARE ME, SOMETIMES! MOVING TOGETHER AS RESEARCH METHOD}

To say this project is deeply personal is an understatement. I bring together a triad of concepts to explore my own experience alongside others like me to understand extended childhood and intergenerational trauma of adult children whose mothers had to leave them behind in order to fulfill Canada's pseudo promise of a "better life." This is a feminist geopolitical undertaking as I include variables of gender, race, class, sexuality, and citizenship to unpack the complex geographies of emotion that the Live -In Caregiver Program (LCP) posits for its participants and their families. I argue that Filipina caregivers queer the precariousness of everyday life through transnational mothering by having to care for their own children and another woman's children simultaneously in two or more national contexts (transnationally).

As I read, listen, and interpret for this project, I find myself needing to take breaks from seeing and hearing myself in the statistics, studies, and stories of academics who have written extensively about the LCP and Filipino migrants more generally, such as Robert Diaz, Geraldine Pratt, Valarie Franciso-Menchavez, Martin Manalansan, and Ethel Tungohan. The epistemological position that I am beginning from is within myself. Having been a sponsored dependent through the LCP and having a shared experience with my mother as she struggled to establish a life for herself once her time as a caregiver was over is deeply intertwined with my project. Thus, the most compelling aspect of my research is my insider standpoint. This positionality allowed for the easy use a semi-structured interview guide (Appendix A). I left all questions intentionally open ended and engaged in a mostly free-flowing conversation with my participants. 
The advantage of being an insider and having overlapping experiences with my participants is that I speak the same language of diasporic yearning felt by the Filipinx youths I interviewed even when it is not communicated. Affective experiences are sometimes not communicated and can only be felt because they are particularly difficult to articulate through traditional interviews. The powerful feeling of seeing someone and being seen by someone who is just like you and has undergone the same experience is undeniable. This feeling grounded by connection with my participants is akin to the attachment one has to their favorite book or quote.

The feeling can be described as a pull, drawing you to the subject matter in ways that you cannot explain because the feeling starts to take over your entire body. From gathering the literature, to conducting the interviews, interpreting the data, to writing my participants' experiences, all of it came with emotions such as empathy, anger, hope, and inspiration. Sometimes I would feel one of these feelings - and sometimes I feel them all at once. Regardless of its occurrence, its presence is enough to validate this project's importance. My proximity to my research topic is a double-edged sword. Interviewing others who have also experienced family separation has the potential to be a challenge as well as an advantage.

I felt this challenge deeply when I was reading an existing scholarship on the LCP that deals with family separation, abuse in the home, failing school, and substance use. The pain of having to detach yourself to get through reading about the experiences you had in childhood in the data, analysis, and the conclusions that scholars such as Geraldine Pratt, Ethel Tungohan, and Martin Manalansan have published is overwhelming. I understand and now move with this challenge, let it push and pull me in, and am thankful that I am aware of it and have grown to use it to drive my thinking. The life inside the literature connects with the life in me and helps me 
come up with practices of self-care for myself as I conduct my interviews and also insider knowledge to be shared with my participants.

\section{Documenting their lives with care}

Given the current restrictions during COVID-19, I posted a recruitment call on social media platforms, specifically Facebook, Instagram, and Twitter. Additionally, I used snowballing to recruit participants in Toronto and Ottawa. I actively encouraged participants to tell others who might be interested. I used a project Gmail address for all communication in the study. All participants met the general sampling criteria of being youth between the ages of 18-30 who were sponsored to immigrate to Canada by a parent who was a former participant of the Live-in Caregiver Program. I conducted five interviews and each of lasted over forty-minutes. All interviews were completed between June and August 2020. See Appendix 2 for a demographic table that includes their pseudonym, age, gender, and time of arrival in Canada.

All those who agreed reviewed and signed an informed consent form. Knowing the challenges that reading about my life presented for me, I wanted to make sure that participants understood what I was asking of them and my sincerity in listening to their stories. A copy of both the Letter of Information and the Informed Consent form was attached to the recruitment emails and follow-up email with participants. For every interview, I reviewed the contents of the consent

form to ensure participants had a complete understanding of their role, responsibilities, and rights in the study. I reiterated that participants could withdraw from the study at any point during recruitment and up until one month after the interviews had taken place. If an interview participant 
decided to withdraw, the digital recording of their partial interview, research notes, and the transcript (if the interview has been transcribed by that point) would be deleted.

I used object-based interviews to ask my participants about their everyday activities, relations, and engagements. These visual materials were objects they use and engage with in their everyday lives. I started by asking participants to bring a chosen artefact or object to the day of the interview, which was explained during the recruitment phase via email. The object was intended to be something that reminded them of home and/or signified disruption or changes in home. I started by asking permission to photograph the object that the participants brought while they completed a generic demographic form. No personal identifiers were photographed. Interviews were digitally recorded. Digital files are stored on a USB key using password protection. Participants did have the option to not have their object photographed but no one seemed to mind.

Due to the subject matter and my own difficulties with it, protecting the participants' identity was and continues to be my number one priority. It was important for me to provide them with as many options as possible. The object that they were asked to bring was not mandatory, but all took me up on it. These objects became key artifacts facilitating our conversation about how they negotiate their lives, identities, and familial/kinship relations as they navigate their postmigratory lives in Canada. All digital audio files and transcripts were anonymized using a unique identifier and pseudonyms.

\section{The importance of everyday objects}

I incorporate photography into my project because pictures are proof of a human choice being exercised (Berger, 1980, p. 217). I asked participants to take a picture of their objects and send me 
the picture via the project email. By including these photographs in my project and thinking about it as a choice, I seek to confirm my belief that people who experience some form of diaspora or an abrupt dislocation carry with them an object that helps them feel safe.

Ann Cvetkovich (2003) states that "fetishization of objects can be one way of negotiating the cultural dislocation produced by immigration" (p.118). Cvetkovich (2003) then tells the story from Achy Obeja's semi-autobiographical story about migration from Cuba through the object of a sweater. The sweater served as a tool that enabled the reccolection of painful memories such as failing school due to difficulties with English, witnessing her father trying to take his life through suicide, and trouble finding a home (p. 118).

Similarly, James Hewitson (2009) highlights the importance of objects - also known as "props"- to convey a specific message; because props are an essential object when trying to narrate a picture that has story-telling qualities they can make an abstract idea more concrete (p. 49). I used photography in my object-based interviews because feelings such as sadness, joy, love, despair, guilt, humiliation, and grief are embedded in objects. The object served as a discussion prompt that aided my participants' navigation through the tangled-up mess of their emotions. The focus of my method for this project is less on photography, and more on the power of objects in relation to people's emotional lives.

\section{I feel them, they feel me: My emotional research}

I use emotion to underpin my methodology because "emotion is vital to systemic knowledge" (McCann, 2016, p. 228). My project responds to existing research, most notably by Geraldine Pratt, on the increased rates of mental health concerns such as depression, and violence turned 
inward (i.e. self-harm, substance use, increasing risk taking behaviors) and outward (gender-based violence, aggressive behaviors) among adults who were sponsored as dependents by participants of the Caregiver program (formerly LCP). The majority of participants under the former LCP program were from the Philippines, and the caregivers' labour continues to be devalued. There is research about these women in Canada, but very little is known about their sponsored families.

Ethel Tungohan (2013) states that it is difficult to draw conclusions about whether or not the absence of migrant mothers leads to lasting emotional trauma despite the mothers' efforts to maintain the relationship by parenting transnationally (Tungohan, 2013, p. 48). However, in the same year Geraldine Pratt published a book titled Families Apart: Migrant Mothers and the Conflicts of Labor and Love where she conducted interviews with 27 families to document the effects of the LCP on children who have experienced separation and reunion (Pratt, 2012, p. 16). The conclusion from her study in Vancouver was that Filipinx youths were more likely to dropout of high school and have lower grades, and in some cases, it would lead to family separation with the child running away from home (Pratt, 2012, p. 28).

What this debate reveals is a cyclical system of a mother leaving her family in the Philippines to take care of another person's family, resulting in her children having a difficult time adjusting to the situation once sponsored for permanent residency to Canada. Then the mother struggles again to support her children at school and to be an active guardian in the lives of her children due to the emotional turmoil that is the LCP (Pratt, 2012, p. 28). Temporary foreign worker programs have always played a key role in immediately meeting shortages in the labor market (Hari, 2014, p. 36). Because of this, Canada sees Filipinx caregivers as disposable, temporary, and 'good enough' to raise white children, but not good enough to be a Canadian. The emotional effect of the LCP deserves attention because care work de-stabilizes Western structures 
of family, nation, and community. Most importantly, Canada sees these hopeful migrants as disposable without taking into consideration the intergenerational hardship that they are perpetuating.

Hannah Dyer and Casey Mecija in their work, Leaving to Love: Filipina Caregivers and the Queer Kinship of Transnational Children, shed light on the fact that Filipina caregivers are caught between structures of neoliberalism and capitalism. They call for more careful consideration of how the children's psychological and emotional topographies are significantly impacted and altered thus perpetuating intergenerational trauma (Dyer, \& Mecija, 2018, p. 554). What is even more interesting is that Filipino/a youth experience and internalize two modes of racism: their experience of their heritage of being Filipino/a, and the superiority of whiteness in Canada. Therefore, Filipino/a youths are caught between the effects of Canada's colonialism and settler-colonialism (Pratt, 2015, p. 306). This duality of experiencing both colonialism and settlercolonialism after reuniting with their immediate families after extended periods of living apart and settling in a new host country can have damaging effects to the individual, especially if they are unable to access appropriate resources and support. Although much is known about the labor market experiences of Filipinas arriving under the LCP and the costs of transnational families living apart, few researchers have followed sponsored dependents of former participants of LCP to better understand their experiences of navigating the complexities of families living apart and reuniting after prolonged periods of separation.

In conclusion, the inspiration for this project that continues to fuel me stems from the strong feeling for connection, as I interview children who, like myself, have been sponsored for permanent residency through the LCP to ask them about how they negotiated their lives, identities, and familial/kinship relations as they navigate their post-migratory lives in Canada. When I started 
to reach adulthood, I found myself demanding to be listened to because I started to understand the layers of my complex, and often contradictory feelings, as I was coming to understand my childhood through the representations I found in the diaspora and transnationalism literature.

In the following chapters, you will meet three of my interview participants: Vendeta, Chini, and Lisa. Within each chapter, you will have the opportunity to read long excerpts of the interview transcript that focus on the migration experience from the perspective of the child. It is my goal by the end of each chapter to encapsulate the experiences of childhoods that are wrought under colonialism and globalization. As a result, their experiences are left outside of the normative theories of childhood development and the children are left without having resources to understand their upbringing. 


\section{"THIS IS FOR MY MOM": SACRIFICES AND ASPIRATIONS}

I first told my mother about this project when I started recruiting participants. At first, I was apprehensive about telling her why I was looking into the Live-in Caregiver Program (LCP) and its impact on the children who are "left behind," as we are described in the literature (Pratt, 2012). Having been born in the Philippines and experiencing eight years of family separation makes this project deeply personal because I am a product of my own topic and continue to live with the implications of my childhood. Hannah Dyer and Casey Mecija (2018) suggest that there is a lot to be said about children who must witness their mother privilege the care of another child over their own (Dyer \& Mecija, 2018, p. 545). When I was in the final year of my undergraduate degree, I was taking a course called Sexuality, Race, Resistance and the professor showed a documentary called Paper Dolls (2006), written and directed by Tomer Heymann, which explores Filipinx at various stages of gender transition who build their new lives in Israel as caregivers to elderly Orthodox Jewish men.

In the midst of the documentary, I abruptly left class, took my notebook, and cried in the hallway. Figure 1, My first public outcry, is a photography of writing in my notebook, which I view as my emotional brain dump of my feelings, some of which still resonate with me today. I have included below the parts I find most relevant to the discussion here:

\footnotetext{
"The word Filipina is starting to sound like an object to me"

"This is what I can't wrap my head around borders and citizenship. How can a person's existence be determined based on a piece of paper?"
} 
"I can't even begin to imagine the amount of work and pain my mother had to go through when she tried to get me to Canada and leave my dad. This is what it probably feels like to live in the diaspora."

Now written three years ago, it was just as hard to read as it was to write. In particular, I am drawn to my words here: "Filipinx women are seeking a future in other countries just like my mother and they are getting beat, ignored, and dehumanized in the process". Knowing that this was often the reality for Filipinx caregivers highlighted for me the sacrifice that my mother and other Filipinx caregivers had to make in order to have a better future for themselves and their families. Although the film was based in Israel and focused on gender non-conforming Filipinx migrants, Paper Dolls strongly affected me because the documentary showed me that Filipinx people are disposable, disdained, and destined to become caregivers, and nothing more. 


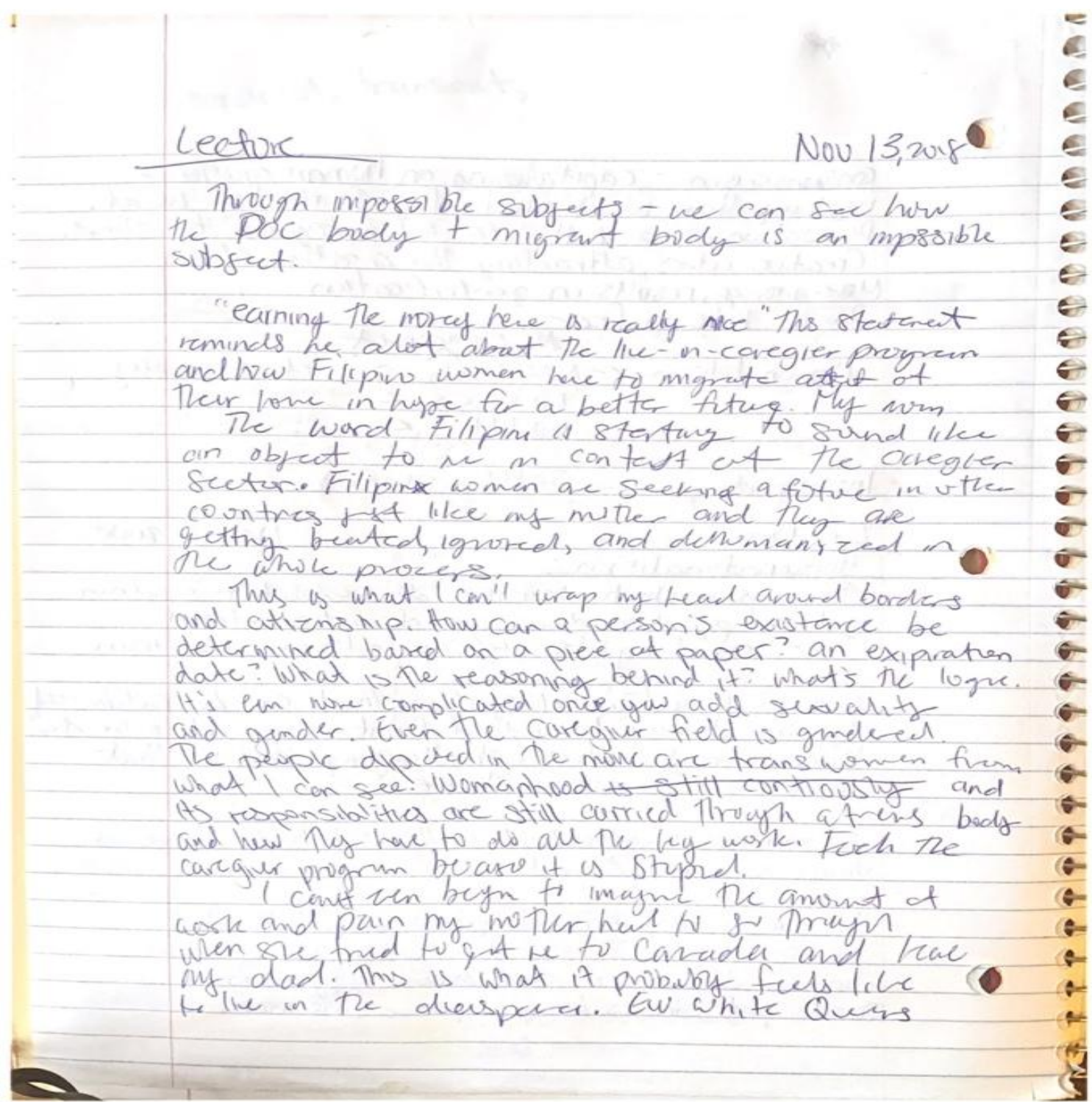

Figure 1: My first public cry 
My feelings of shame only started to develop when I moved to Canada because I was different from my white peers - both physically different and different in the ways in which we grew up. I grew up without my mother and without a father; instead, I was raised within my community and extended family. I grew up playing in lakes and rivers, and I helped my family pick vegetables on the farm so we could have something to eat. I grew up riding motorcycle taxis to get to school. In hindsight, I recognize it was probably extremely dangerous because the motorcycle taxis would be filled to the point where my classmates and I would have to sit on top of each other, the roads were bumpy, and no one was wearing a helmet. I grew up climbing mango trees and catching frogs and fish to eat for dinner. Even now when I think about it, I love the way I grew up because it made me dexterous.

As an adult reflecting on these memories I feel as though I experienced childhood twice, the first time being my unadulterated experience of childhood and the second, a colonized experience of childhood. My childhood in the Philippines was filled with lots of love and joy because I was surrounded by a community that helped raise me. However, my second experience of childhood when I moved to Canada -- my colonized childhood -- was filled with a lot of confusion and shame.

I carried this strong feeling of shame when I entered the Canadian school system because the nuclear family structure was so heavily imposed by the system. As a result, I frequently questioned my upbringing in the Philippines and, most importantly, wondered if my mom really did love me and if she wanted me as her child. These feelings deepened and were emboldened during forced Hallmark assignments, such as crafts related to "Happy Mother's Day!" or "Happy Father's Day", which I detested. Lastly, "Family Day!" made me feel shameful and hateful towards my mother because our family dynamic and my upbringing was not like that of my classmates. 
This experience was my first encounter with whiteness and the start of the rejection of my Filipinx identity.

\section{The best of both worlds: Moving and grooving}

Filipinx youth experience and internalize two modes of racism: their experience of their heritage as Filipinx, and the superiority of whiteness in Canada. Therefore, Filipino/a youth are caught between the affects of colonialism and settler-colonialism (Pratt, 2015, p. 306). This dual experience of both colonialism and settler-colonialism, when reuniting with their immediate families after extended periods of living apart and settling in a new host country, can have damaging effects, especially if people are unable to access appropriate resources and supports. My conversations supported Pratt's (2012) early observations of Filipinx youth. For example, when my participant Vendeta was about two months old, his mom asked her sister to assume full-time parenting responsibilities while she came to Canada as a caregiver.

Vendeta was born in Saudi Arabia, and moved to the Philippines when he was two months

old. Vendeta grew up with his aunt (mom's sister) and was sponsored to come to Canada in September 2015. When I asked Vendeta "Did you know that you were going to come to Canada?" he replied:

Yeah, it was something that I always knew but I didn't want it to happen. I knew that I always wanted to be closer with my mom, and so moving to Canada would help us become closer because it would give her the chance to become a mom... that's how I rationalized it to myself. When I came to Canada, it was a depressing moment for me for about two years. I didn't have friends because I just kept working so I can earn enough money to go home. I also didn't know how to take care of myself, and I gained weight. A lot of weight because my life in the Philippines was the best life I ever had. 
When I asked Vendeta, "In what ways was your childhood different in Philippines versus Canada?" He replied:

Because my life in the Philippines, I grew up in a farmland so everything was simple. Whatever you need, whatever you want to eat - it's just there. Life there is hard because whatever you want, you have to work for it - agriculture wise. But you are happy there because you are with people that you love the most. And you don't feel the hardships because you are always laughing.

Vendeta offers us a unique perspective because asking children how they feel and what their thoughts are on immigrating is often left out of the literature on mobility, citizenship, and migration. From Vendeta's point of view, he was perfectly happy in the Philippines and lived a fulfilling life because he was surrounded by those that he loved. Much like other Philippine families who emigrated to Canada through the LCP, the driving factor is the mothers' desire to obtain the "good life" for themselves and their families. In my conversation with Vendeta, he mentioned that he held some grudges towards his mom. I asked him to clarify this, and he gave the following reasons for his grudges:

Yeah, I held a grudge towards my mom because I didn't really know her when I moved to Canada, and she was pushing me to do something that I didn't want to do. For example, she kept pushing me to become a nurse. So, I told her 'you don't know me well enough for you to push me and give me directions in my life'. I am really into the arts and I wanted to get into architecture, and she pushed me into nursing.

The tension between what Vendeta wants for his future and what his mother desires him is a common dynamic between immigrants and their children. Education and migration are two sides of the same coin which signifies mobility and shapes ideals around what constitutes a "good life" 
and how to obtain it. Based on the interview transcript above, we can make the assumption that Vendeta's mom sacrificed a lot in order for Vendeta to have an opportunity at achieving a life without hardship. Through her concept of cruel optimism, Lauren Berlant gestures towards the problematic nature of the "American Dream" under neoliberalism. Berlant uses the term "clusters of promises" to describe the desire for someone or something to make to us, or make possible for us (Berlant, 2011, p. 23). Berlant states:

All attachments are optimistic. When we talk about an object of desire, we are really talking about a cluster of promises we want someone or something to make to us and make possible for us. This cluster of promises could seem embedded in a person, a thing, an institution, a text, a norm, a bunch of cells, smells, a good idea - whatever. To phrase "the object of desire" as a cluster of promises is to allow us to encounter what's incoherent or enigmatic in our attachments, not as confirmation of our irrationality but as an explanation of our sense of our endurance in the object, insofar as proximity to the object means proximity to the cluster of things that the object promises, some of which may be clear to us and good for us while others, not so much.

(Berlant, 2011, p. 23).

Filipinx caregivers who leave their families in the Philippines are attached to an "object of desire" that is ultimately Canadian citizenship. Their endurance in navigating Canada by themselves and leaving their families speaks to the cluster of promises that the LCP posits. Berlant (2011) articulates the connection between "cluster of promises" and "the good life" often referred to by my participants:

At the center of the project, though, is that moral-intimate-economic thing called "the good life." Why do people stay attached to conventional good-life fantasies - say, of enduring reciprocity in couples, families, political systems, fragility, and dear cost abounds? Fantasy is the means by which people hoard idealizing theories and tableaux about how they and the world "add up to something." What happens when those fantasies start to fray - depression, dissociation, pragmatism, cynicism, optimism, activism, or an incoherent mash (p. 2). 
Vendeta's mom wanted so badly to live the "good life" that she left her son at two months old to live abroad and take care of another family's children. Her attachment to living the "good life" harmed Vendeta and their relationship because of the years spent living apart. The harm continued as Vendeta dealt with the looming relocation, which gain led to him experiencing two years of severe depression after his move to Canada.

Berlant (2011) perfectly illustrates how "all objects/scenes of desire are problematic, in that investments in them and projections onto them are less about them than about what cluster of desires and affects we can manage to keep magnetized to them" (p. 24). Migrant caregivers, such as Vendeta's mom, choose to leave their families to become caretakers abroad, constructing a cluster of promises, which creates a cluster of problems for Vendeta. These problems constitute into a grudge that Vendeta had towards his mom, a direct result of the cluster of promises imagined within transnational families. Temporary foreign work programs such as the LCP further perpetuates temporariness and exemplifies Canada's history of hiring migrants for cheap labor.

According to the "Landing Program", temporary domestic workers were allowed to apply for landed status only if they could demonstrate "self-sufficiency" or "the potential to achieve selfsufficiency", which was evaluated through interviews with immigration officers. If they lacked "self-sufficiency" they were given an extension of one or two years to upgrade their skills (Cohen, 1994, p. 2). What follows is a further analysis of Berlant's "cluster of promises' ' and "the good life" as illustrated through the relationship between Vendeta and his mom. 


\section{Hear me Out!: Transnational Hyper-maternalism and "Cluster of Promises"}

Vendeta has a myriad of feelings about his mother. When I asked him "Do you share your migration story with others? Such as her taking care of another child while you are back home in the Philippines?" He replied:

She is always talking about it. She is always telling us that it hurts that she hasn't seen our success as a child. It hurts that I didn't see how I progressed in life through elementary school and to college. She is always crying whenever she says this. But most of the time I tell her that she chooses this life. It was her responsibility. I kind of get angry sometimes when she always says this in a way of pity. I told her that we didn't want her to leave. And she chooses to leave. But at the end of the day, I always feel guilty when I say that because maybe more than ten times we talk about it and I feel very guilty because I've see the hardships that she's had but I just don't know how to go low. Low as in magpakumbaba (humble) because I feel like I was angry. She left us when she didn't have to. She didn't have to go away just for money. But she did. At the end of the day, she did it for our future and that's what we get right now. We are professionals now and $I$ owe it to her. I always dream about leaving Canada and maybe living in the States but right now I can't because my parents need me. They need help with technology, house bills, and if they wanted to apply to a job, I am the one who is applying for them. And if they need something - for example renewing their license. I am doing it for them. I try and teach them how to, but they always forget it. So, I feel like they won't be able to live here in Canada without me.

This lengthy quotation reveals in Vendeta's own words, a myriad of feelings a child labeled as "left behind" by the global care chain literature pertaining to the LCP. Scholars such as Geraldine Pratt, Ethel Tungohan, and Rhacel Parreñas have written extensively about children "left behind."

There is a lot of confusion, pain, regret - yet all of these feelings orbit around the feeling of love.

In Vendeta's response, we also get a glimpse of not only his feelings but also those of his mom who had to leave him and sacrifice herself as a mother in order for to secure a better future: the 
promise of "the good life." The layers in Vendeta's response illuminate how complex the material realities are of children who were once part of a nuclear family in the Philippines, and then transitioned to a transnational family dynamic to accommodate for their mother's role in global chains of care. To better conceptualize this, I want to draw on Ethel Tungohan's (2013) concept of transnational hyper-maternalism, which is the idea that female labour migrants are expected to be their families' economic saviors, while also fulfilling their maternal responsibilities overseas (p. 39). Transnational hyper-maternalism, then, allows for women migrant workers to overcome accusations of maternal and familial neglect.

Vendeta's mother is always telling him about the sacrifices that she made in order for them to have a better life. However, in Vendeta's response, there is a dissonance between the ways in which transnational-hyper-maternalism is portrayed and how it is actually perceived from the perspective of the so-called "left behind" child. There seems to be no room for Vendeta to explore his desires and hopes for a different future that are solely his own. Though this is a weighted statement, it is evident that there is some expectation of intergenerational filial obligation or duty. His mom became a live-in caregiver for him and sacrificed her future and maternal identity for him, and now what he must do in return is fulfill his mom's cluster of promises.

In using Berlant's cluster of promises in tandem with Tungohan's articulation of transnational hyper-maternalism, we can see how children are now expected to become the economic saviors of their families by sidelining their individual desires. What I find interesting is that in the field of child studies, children's rights are asserted - yet feelings such as hate and aggression, which are born out of insecurity and vulnerability, are generally undertheorized (Dyer, 2017, p. 294). This is why we see drastic shifts in Vendeta's responses to my questions -- often flipping between hate, love, and understanding. 
The social world of a child is hard and confusing. Their affects are interpersonal, often resulting in anger, hate, remorse, and shame. To think that a child is unable to understand what is happening is a disservice to both the parents and overall health of their familial relationship because ignoring the ways in which the child is affected by migration is denying the reality that the child is experiencing. Thus, in the context of the LCP and its impact on families, "the good life", "cluster of promises" andtTransnational hyper-maternalism are dominated by the identity, behavior, attitudes, and sacrifices of the mother, which in turn, their children are expected to fulfill and reciprocate.

\section{Understanding emotional fluidity: What goes around, comes around}

When I asked Vendeta "do you think you owe your mom a certain measure of success?". He replied:

I owe her everything. I owe her everything. When I saw the way that she worked for us here, I felt it. That's when I knew that I owe her everything. My profession I owe it to her, my life I owe it to her. My career right now I owe it to her. I owe EVERYTHING. Every time I come home from work I tell her "hey mother, how are you? "and I tell her "you don't have to work too hard anymore. Rest your body right now, we are already professionals. Give me the chance to pay you back whatever you are supposed to have right now which is a better life. Not a working life.

Vendeta came to this realization when his mom asked him to accompany her while she cleaned a house on Christmas Day. Vendeta saw how big the house was and thought "there is no way one person can clean this house in just a few hours" and so he decided to help. 
She told me to turn on the vacuum and that she will do everything else. I felt like it was easy and when I saw that my mom was doing all the other stuff and I felt really bad. I felt bad because I didn't have the guts to look at her when she was on the video call when I was in the Philippines. But right now, I see her in reality and how laborious her work is just for her to be able to give us money back home. That was so painful for me. That was December 24, 2015 and I said, "this is how you celebrate Christmas without us?" and when I went home, I was crying because I felt so stupid and I felt so bad that I did that to my mom. Because she gave us everything but I didn't show her the love that she deserves.

(Vendeta)

The realization that Vendeta had when he saw his mom cleaning houses on Christmas day was transformative for himself and for their familial relationship. Vendeta's story echoes Geraldine Pratt's (2012) observations in Families Apart: Migrant Mothers and the Conflicts of Labor and Love. Pratt (2012) shares one of her interview participant's responses: "my daughter was surprised. She asked why I was poor here. Of course, in the Philippines she had everything, since I was sending money every month to take care of her. In the Philippines, she was maybe living a middleclass lifestyle. But not here" (p. 33). When I read this, I was hit once again by a wave of emotions, and I felt as though I was reading about my childhood but from my mother's perspective. When I came to Canada, I really thought that my mom and I were well off because I felt that way while in the Philippines. Through Pratt's (2012) participant response and Vendeta's story, the invisible labor of migrant caregivers is made visible through the ways in which the children are affected and the children's often emotional journey from living apart to reuniting with their mothers.

Children of the Filipinx caregivers who are participants of the LCP are left confused, remorseful, and heartbroken due to their mothers leaving them behind. Meanwhile, the children whom the Filipinx caregiver is taking care of are able to have someone look after them and meet their immediate needs during their developmental stages. Ultimately, temporary foreign work 
programs such as the LCP are used solely as a tool for Canada to meet shortages in the labor market (Hari, 2014, p. 36).

Global Care Chain theories make the assumption that the presence of the biological mother alone determines a child's well-being and that emotions are fixed and stable; therefore, the love that migrant caregivers have for their own children cannot be transferred on to the children that they are taking are of (Tungohan, 2019, p. 5). Filipina caregivers are caught in the complexity of migration, the aspirations of citizenship, and the demands of loving and caring for their own children transnationally, whilst loving and caring for the children of their employers. FranciscoMenchavez points to how migrant children's feelings towards their parents shift over time, and as they grow older, they learn how to make sense of the reasons why their mothers had to leave (noted in Tungohan, 2019, p. 6). When migrant children come to this understanding and realization, similar to what Vendeta experience, it is often followed with feelings of regret due to not knowing the sacrifices that their mother made. These feelings of regret enable migrant children to aspire for a better life than the one they already have as a way to show appreciation to their mother.

Vendeta's story makes me question: will there ever be a time when migrant children and transnational families will be able to make decisions that are solely for them, where their safety and livelihood will be secure without the fear that their family will crumble? Or will the cycle of transnational hyper-maternalism, cluster of promises, and children fulfilling their parent's desire to be the ultimate reality for transnational families' due to the history of colonialism? These questions that I pose at the end of this chapter are ones that I cannot answer; rather, these questions offer a space for exploration and careful consideration when analyzing childhoods that are missed in normative theories of childhood development. Though it is common that sponsored children by former participants of the LCP, such as myself and Vendeta, often come to understand why our 
mothers left, the interview transcripts included in this chapter provide evidence that "childhood" is not a thing of the past. Rather, childhood is a formative phase in our life, where the experiences that we have, and the affective traces they leave, linger throughout our lifetime. Through the relationship between Vendeta and his mom, we can start to make sense of the complex emotions that arise within transnational families from the time of separation to reunification and for a long time after. The LCP program, Berlant's “cluster of promises”, “the good life”, and Tungohan's transnational hyper-maternalism are concepts that can add to the conversations about transnational family separation and family reunification through specific immigration pathways. It is through these concepts that we can begin to uncover feelings that seem to be overlooked by migration and transnationalism studies on families, kinship, and care. 


\section{HELP! EVERYTHING IN MY LIFE IS TURNING QUEER!}

Chini is twenty-six years old. He identifies himself as bakla in the context of the Philippines, and in Canada, he identifies himself as a gay man. What is so compelling about my conversation with Chini is the ways in which he brings to the surface the importance of chosen kinship and intimacy - something that has always been at the core of queer culture. However, Chini's story reminds us that "using approaches, styles, and methodologies that are Anglo - American or European limit the ways we think about being queer" (Anzaldúa, 1991, p. 265). This is why "queer diaspora emerges as a critical site providing new ways of contesting traditional communities based not on origin, filiation, and genetics. But on destination, affiliation, and the assumption of a common set of social practices or political commitments" (Eng et al., 2005, p. 7). This chapter adds to Manalansan's work regarding Filipino gay men in the diaspora, as Chini explains his gender identity and shares with us his childhood experiences of living in the Philippines, and his involvement in the queer community.

Bakla and queer are identities Chini uses simultaneously. He uses bakla to self-identify and signal to others that he is a gay man and mobilizes his queer identification to signal his political disposition in the Canadian context. Bakla and queer are both his identities, which he uses in different ways to signal his sexuality and his political stance. "Bakla symbolizes Filipino queerness, while gay symbolized white queerness" (Manalansan, 2003, p. 24). Furthermore, Manalansan (2003) breaks down the gay identity into 3 categories:

1. Escaping from biological familial bond where the sense of self becomes dependent upon individuation, separation, and leaving home. 
2. Sexual object choice, or who you have sex with, as the primary and singular defining factor.

3. A conscious acknowledgement of a "man" who desires to have sex with other "men." (p. 23)

Gay identity, as articulated by Manalansan, can be understood into three phases that arose from the Stonewall Rebellion in New York City in 1969. However, he argues that the bakla identity "invokes particular kinds of scripts that point to notions of a self-embedded in social relations. I suggest that the bakla identification involves a process of continually performing according to changing stages or performative spaces and conditions. Therefore, bakla is not an identity that is assumed by particular men, but more accurately is a slippery condition, a performative event or series of events of self-formation. (Manalansan, 2003, p. 186). Ultimately, through Manalansan, I came to understand the bakla identity as being fluid; it is an identity that is able to shape-shift depending upon the individual who identifies as bakla. The bakla identity is a way that Filipinos are able to hold their race at the face of Whiteness.

The queer studies literature establishes that people make sense of their identity in a variety of ways. Chini's story reveals these identities as they intersect with his diasporic identity and reality. He is queer and diasporic - bakla for him captures this intersection. Gloria Anzaldua, similar to Manalansan (2003) reminds us of the limitation of "queer" as a false unifying umbrella that unifies all races, ethnicities, and classes, thus erasing individual stories and creating a dangerous single "queer" story (Patrick, 2001, p. 3). As this chapter unfolds, my aim is to articulate the strategic ways queer Filipinx have learned to master what Narayan (1989) gestures to as "epistemic advantage" because they had to learn the language and culture of their colonizers (p. 
267). Chini had to learn the language of his colonizer at a young age, and to help illustrate this, I am going to borrow Hannah Dyer's (2020) queering of childhood innocence and development. I attempt to convey the ways in which Chini, and those like him, are not protected by innocence as it is understood by normative theories of child development, as critiqued by Dyer (2020). Rather, Chini's childhood is strongly rooted in forms of race, class, gender, and sexuality that are influenced by global capitalism, environmental ruin, and colonialism.

I also engage with Megan Rivers-Moore's work on sex tourism in Costa Rica, in particular her nuanced and complicated discussion of care and social mobility. Rivers-Moore identifies and advocates for the importance of adding sex to the category of care work. Through this logic, we can begin to reimagine our assumptions about love, affection, and sex. Rivers-Moore (2016) beautifully draws the connection between sex work as care work by providing us with the perspective that mainly goes unacknowledged: we do not assume that nannies feel affection for children for free and that asking for payment for care does not make it any less significant. Thus, giving companionship, empathy, and sexual exchange to clients is important to consider because love, care, empathy, and camaraderie are all aspects of care (p. 88). Through Rivers-Moore's articulation of sex work as care work, she makes clear the ways in which transnational care work, of whatever form, involves a transfer of love, affection, and payment. The following interview transcript with Chini is central to my attempt to weave together the concept of childhood innocence and sex work, and expressions of care to demonstrate how histories of colonialism extend into the future. 


\section{Queer Futurity}

PJ: What were some of the memorable moments from your childhood in the Philippines?

Chini: When I was younger, I had a gay best friend. We were still little but we both knew that we were gays. I don't remember how old we were - maybe six or before six. We would talk about guys and some of the things that we talked about are just simple things in life like what colour do we wanna wear, what game do we wanna play. We do talk about guys in terms of celebrities and all of those things. To me, I still didn't fully understand want it means to be gay. But I just knew that I was different. That's probably why we really bonded together and even until now, that I'm in Canada and he's in the Philippines - whenever I visit, we make the time to meet each other.

When we were?teenagers, there was some tension between us. I don't know if it's because we're gay - so people would compare us two and say "look at him he looks nicer" "look at him, he looks smarter" there was that tension.

PJ: Tension as in "who was the better queer?"

Chini: For me, the comparison I felt was heavily related to the stereotypes because when you think of gay people, they think breadwinner of the family, they think of you as the provider. My friend told me "you will never see a homeless gay person in the Philippines" because we know how to be resourceful, we know how to survive. That's what they told me at such a young age. Growing up in the Philippines - I never met a homeless gay person and that's because they are resourceful. Because they can always find ways to contribute and provide for their loved ones.

PJ: That's very true. Our identities are already so stigmatized and we already know how it feels like to be excluded and therefore inclusion is in the forefront of our minds

Chini: I remember all the life skills that I learned was because of the gay community. In school, back then, they didn't teach anything about sex, they didn't teach anything about keeping yourself clean. It was the older queers in my community that taught me how to use a condom, and how to keep myself clean and safe. They taught me ways that I could protect myself if a group of guys saw me and they started becoming homophobic and aggressive. What would I do in those cases? I learned a lot of survival kits from them.

PJ: How do you understand family? 
Chini: I was very close with my queer community. It was only in Canada where I learned about houses When we were watching TV and sometimes they would have US Drag Race. Obviously back home we had that structure. We didn't label ourselves as being the house of this or the house of that. It was always the older gays who gave us guidance and who gave us advice and who also financed us in case we needed it. I remember getting free haircuts, and getting a lot of free stuff and they would dye my hair. I was fourteen when I started selling street food and it was them who taught me how to sell street food. They taught me how to navigate pyramid schemes. And sometimes when I think about it, some of the things that they taught me - I can be critical of it. Like back home, we would chat on the internet with white men and we would pretend to be females even if you're not. I remember them telling me "hey, why don't you go into these online platforms and just look for white man and just pretend that you are a female and if they want to speak to you on the phone, just get someone who is a female to talk to him." So those things were some things I did to get money.

PJ: Is it fair to categorize this as sex work? what you just told me?

Chini: Yeah I think so. Because there are things involved such as showing private parts.... So yes, yeah. So when that white person would come and visit in the Philippines there's actual sex involved. But beyond that - there was emotions involved. I know some people who came to Canada because they married that white person and now they have kids of their own. So it depends... it's more common among the older Filipinas to take the serious relationship route whereas the younger ones - it's easy money for them.

The ways in which Chini was taught how to navigate pyramid schemes, sell street food, and fake attraction and sexual pleasure at what could be thought of as an impressionable time in his life, based on normative theories of childhood development, speaks to how histories of colonialism extend into the future. In the Philippines, children like Chini are taught these forms of bargaining because of the economic uncertainty and political ruin of the nation-state, as a direct result of Spanish colonialism and its continuing vestiges. As mentioned in Chini's response above, for younger queers, it was about easy money whereas the older queers partook in sex tourism in hopes of migration and the promise of citizenship somewhere, anywhere, other than the Philippines. Thus, the performance of sexual desire is key to caring practice within sex tourism 
(Rivers-Moore, 2016, p. 79), which was interpreted in different ways by different generations of queers in the Philippines.

At a young age, Chini learned how to survive and take care of himself amidst increasing poverty in the Philippines. The Western ideals of childhood innocence and its relation to theories of child development suggests that children are too young to deal emotionally and cognitively with concepts rooted in struggle, survival, and procreation (Garlen, 2019, p. 55). Through this logic, we can argue, as others such as Robin Bernstein, Julie Garlen, Kerry Robinson, and Hannah Dyer to name a few, have argued, that the concept of childhood innocence further perpetuates white supremacy because only white kids were allowed to be innocent.

Chini shares:

I remember all the life skills that I learned was because of the gay community. In school, back then, they didn't teach anything about sex, they didn't teach anything about keeping yourself clean. It was the older queers in my community that taught me how to use a condom, and how to keep myself clean and safe. They taught me ways that I could protect myself if a group of guys saw me and they started becoming homophobic and aggressive. What would I do in those cases. I learned a lot of survival kits from them.

Chini's reflection exemplifies what Robinson (2012) identifies and advocates for: "streetwise children," who are often neither white nor middle-class, are hard to square with "children." Children who are perceived as disorderly, disobedient, chaotic and uncontrollable not only lose their status as innocents, but their identity as children is also questioned (p. 44).

Chini pronounces: "My friend told me "you will never see a homeless gay person in the Philippines" because we know how to be resourceful, we know how to survive. That's what they told me at such a young age. Garlen (2019) warns that "fantasies of childhood as a blissful epoch of care-free enchantment is a powerful social construct that scripts an expectation for what 
children's experiences 'should' look like" (p. 55). Ultimately, "childhood" is maintained and reinforced through the logic of protection, and is then operationalized through protective practices and policies (p. 57) - however, its protective practices do not include the protection of all children. Families that are exposed to ongoing colonialism, globalization, and family separation must become creative in their caring strategies because both the Philippines and Canada deemed them unworthy of protection as outlined by normative theories of childhood.

Chini's reflection below is an example of that. When I asked him, "How would you describe your relationship with your mom when she was away?" He responded:

I am very close with my mom even when she left and when we were apart. She was really supportive and really understanding. And although we were apart, I felt her love, I felt her support, her care. I remember in high school when I was struggling with math - she offered to get me a tutor and there's a lot of things she was supportive and I really appreciate and so when I look back on my experience of living in the Philippines and thinking of her doing work abroad, I don't know how to describe that type of mothering..... and she was really good at that.

The ways in which Chini's mom was able to find a tutor, support him emotionally, and was still able to make her love felt across oceans describes a different kind of mothering that does not have conventional Western language. Valarie Francisco-Menchavez (2018) makes clear for us that the Philippine family is upheld by pakikisama, translated as "being with," which puts an emphasis on interpersonal relationships that organically express feelings of being in the family (p. 5). Chini had the love and support of his chosen family, who helped him navigate his gender identity, and shared personal stories with him. In this unconventional (according to Western constructions) of understanding family, he was able to learn survival strategies shared by his fictive kin. 


\section{The Magic of Storytelling}

What Chini, Vendeta, and myself have in common is our ability to not let whiteness and white queerness win regardless of the countless times whiteness tries to make us shape-shift in order to fit someone else's idea of perfection. It is through this thesis that Chini, Vendeta, and I created space for our narratives to be written into the field at the intersection of diaspora studies and queer studies. As Halberstam suggests that "the future of queer studies depends absolutely on moving away from white gay male identity politics and learning from the radical critiques offered by a younger generation of queer scholars who draw their intellectual inspiration from feminism and ethnic studies rather than white queer studies" (Eng et al., 2005, p. 12).

The English language does not have the right words that Chini, Vendeta, and myself can use to describe our experiences and articulate our liberation. The lyrics in the song titled Heto $\mathrm{Na}$ and performed by an all-women queer Filipinx artists who go by the name Pantayo, which means "for us" in Tagalog describe Filipinx liberation for me. The lyrics are "umindak ka na kaya. Kaliwa dalawang paa. Pakapalan ng mukha" (Ready, set, go strut your stuff. To the left, lock in both your feet. Own up to that funky shit) (Telephone Explosion Records, 2020, March 25). The beat of the song makes you want to dance as it is influenced by the musical genre of upbeat Lo-fi, R\&B gong funk, techno and disco. These lyrics describe my experience of Filipinx liberation because it is sung by queer Filipinx artists, therefore it takes on a whole new meaning that can be felt strongly by other Filipinx in the diaspora. As Gloria Anzaldúa writes in 1991 “when a 'lesbian' names me the same as her, she subsumes me under her category. I am of her group but not as her equal, not as a whole person - my color is erased, my class ignored" (p. 263). Through this, we can start to 
understand Chini's identity and the ways in which he uses both bakla and gay terms to encompass not only his queerness, but also include his color and class.

My proximity to my project makes this thesis, and especially this chapter, personally transformative. This format of storytelling between myself and my participants gave me the courage to tell my family that I am queer. A revelation happened for me at the precise moment when Vendeta, my participant whose story I shared in the previous chapter, talked to me about the ways in which his family was able to accept his gay identity. The excerpt from the interview is as follows:

Vendeta: I can't open up to my dad the way I open up to my mom because his side of the family is very masculine and they just don't like gays. So, I can't share with him who I really am - all he knows is that I have gay friends.

Me: How about your mom? Was she able to accept your queerness?

Vendeta: Oh yes, she accepted me and she supported me right when I told her.

Me: That makes me really happy to hear and it is very inspiring. Now I want to call my mom but I am still very scared

Vendeta: Yeah, you will be having your own time. You will feel the time and you will know that it is the perfect time. It's a hard thing to do because there's a lot in your mind that you are expecting after telling your mom but you can say it when you feel like it. You will feel free, you are free.

When Vendeta said the word "free," I felt that was the word that I needed to hear in order for me to live openly, honestly, and genuinely. If one day Vendeta chooses to read this thesis, I want him to know how much his words propelled me to live a more honest life; and for that, I am forever moved. I have come to learn the importance of words, as they can take on many meanings and be understood in various contexts. When Vendeta said "free," I distinctly envisioned the 
countless times that I betrayed myself, all the while picking myself up and giving myself the opportunity to try again. So, let me re-introduce myself to you. Hello, my name is PJ, I am a queer Filipinx, and I am glad that you are here. 


\section{WHEN THE NU(CLEAR) FAMILY ISN'T SO CLEAR}

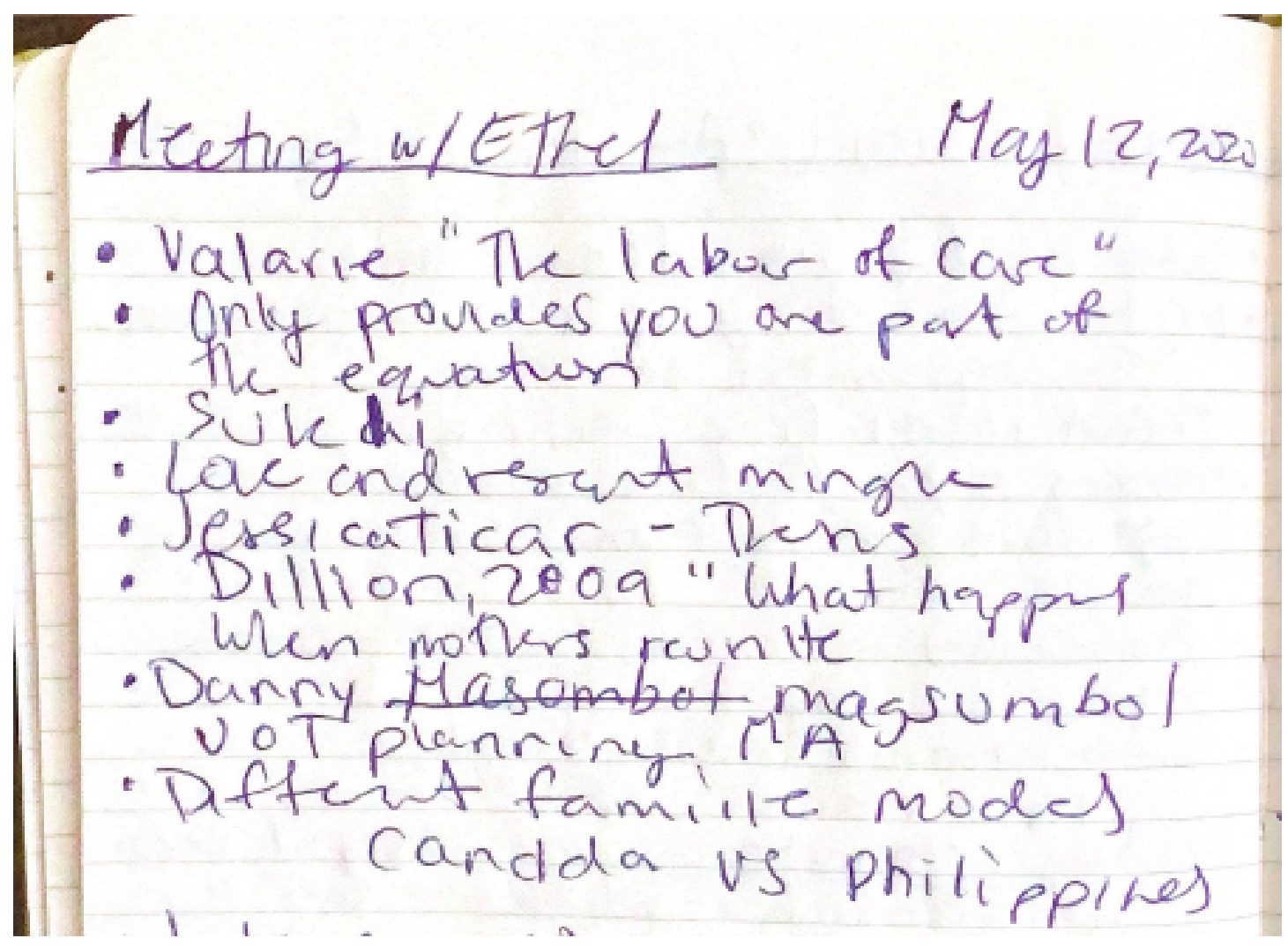

Figure 1: My first introduction to the Filipinx Diaspora

The process of writing this thesis has been nothing but absolutely nourishing. Due to my burning question, and my passion for learning, I had the opportunity to think with incredible scholars who have been influential to the process of writing myself into theory, including Ethel Tungohan, Robert Diaz, Casey Mecija, and Hannah Dyer. I learned a lot as I thought through with them questions of labour, motherhood, and migration. Most importantly, I participated in a collaborative effort to think critically about why and how the Filipinx body has such a queer presence in Canada. 
I include above an image of my meeting notes with Dr. Tungohan where we talked about the LCP because I want to highlight my last bullet point - which reads "different family models, Canada VS Philippines. " I remember writing this down because she gave me the perspective that I was lacking in the beginning of this project, which is that I should be careful about comparing across different countries without a critical interrogation of different interpretations and perceptions of family structures in each context. Informed and inspired by our conversation, my aim here is not to compare family models in the Philippines and Canada and conclude with reasons as to which family structure is better. Rather, my aim is to echo the main argument of Valerie Lehr in Queer Family Values: Debunking the myth of the nuclear family (1999) because she challenges the forms of oppression, such as: gender, racial, and economic - that leads people to privilege the nuclear family (p. 132). I also contribute my critical insight which is that the nuclear family, predominantly enforced in Canada, is limiting because it does not make room for careful consideration of all of the strategic ways that make a family function. I do this by including narratives of youth who come from transnational families to add to the conversations about childhood development and family models.

I arrive at this thought as someone who has experienced both transnational and nuclear family models. The nuclear family reinforces individualism and a greater divide between public life, which is outside of the home, and private life - often understood to be inside the home (Lehr, 1999, p. 19). This divide should be critiqued because the state has the power to set the contract for marriage and child custody - which are considered to be part of private life, yet state interventions into these familial negotiations make marriage and child custody part of public life (LeBaron 2010; Bakker 2007; and Acker 1988). 
Lehr (1999) asserts that we should reject the belief that the state is interested in protecting relationships, such as the nuclear family, which is seen as "natural" but is actually a product of the bourgeoisie. They have defined and reinforced their definition of family life as 'natural' based on close kinship, organized through a male breadwinner with a financially dependent wife and children. This is illustrated in Michelle Barrett's work on different forms that family takes in human societies and the falsity of the "natural" nuclear family (p. 18). Additionally, Lehr (1999) puts forth the arguments by Collier, Rosaldo, and Yanagisako which is that the privatization of family units is directly connected to capitalism because privatized households such as the nuclear family can only function if financial resources are already available - note that I say already available and not given because of economic privilege. This incorporates the idea that financial resources are not given to everyone in equal proportions (p. 20). In many low-income families, the main source of survival is the sharing of resources and redistribution of care. Below is a case study of how Filipino families successfully reconfiguring and redefine caring strategies in order to make their family unit sustainable across great distances.

\section{Lisa's Family Ties}

There are a lot of moving parts to Lisa's story. She was adopted within her family, and as a result, she was simultaneously raised by her family in the Philippines, and transnationally by her adopted parents in Canada. To lay out the family tree - Lisa was born in Bayambang, Pangasinan and was raised by her biological parents until she was two years old. At age two, she was adopted by her uncle and her aunt who were living in Canada, but they wanted Lisa to grow up in Candon, Philippines because that is where her uncle, whom I will now refer to as her dad, and her aunt, 
whom I will refer to as her mom moving forward - had a house. Lisa's parents wanted Lisa to grow up surrounded by family members who all lived walking distance from one another in Candon.

While she was living in Candon, she had a caregiver named Malou. Malou is her mom's niece and she was responsible for disciplining and grooming Lisa for her pending move to Canada. Lisa shares with me:

Malou was always the one taking care of me and grooming me into thinking that I was going to go to Canada, and telling me who my mom and dad are going to be. She was basically trying to convince me that I had a different family. I don't know if she was trying to make me forget that I had a different family in Bayambang but she would tell me every day "you have this family in the Canada and this is what you are going to do in Canada, and you have cousins in Canada".

From Lisa's point of view, she was being told that she would be moving to Canada, while at the same time, experiencing the transition from Bayambang to Candon, and she was also being told who her new parents and family were going to be while saying goodbye to her biological parents. Lisa was being told all of this by another female family member and caregiver when she was two years old, the age where you learn most of your cognitive thinking, learning, and problemsolving. You begin to be able to use both hands, find objects, and play make-believe games. Lisa recalls this experience as confusing and her care and future came down to who was going to ultimately provide her with a life where she has multiple opportunities when she grows up and a life where she is safe and happy. I asked Lisa "I am curious to know how you understood family when you were living in the Philippines?" she responds "I think the whole family thing for me was very confusing... I knew that I had brothers and sisters from my biological parents, and I am moving to Candon because my new parents wanted me to move to Canada was confusing for me.. 
at a very young age, everyone kept telling me that people in Canada love me so much and that I have another family there."

Lisa's adoption process happened and was negotiated within the family, along with the caretaking responsibilities. When I asked Lisa "were your parents in Canada part of your everyday life in the Philippines?" In her response, she was certain and immediately told me "Yes, she always came to the Philippines to see me. My mom was always there since I was born and so was my grandmother who is my biological mom's, mom." There is no doubt that Lisa was surrounded by providers who wanted to take care of her. She later adds to her response "my grand-mother was the one who told my biological mom to give me away. So, it wasn't my biological mom's decision, it was my grandmother who made the final decision that I was going to be coming to Canada." Though I am supportive of communal family structures, and the various ways that transnational families spread love across great distances, Lisa's response caught me by surprise. It caught me by surprise because her story exposed me to a new perspective on the process of adoption. Fueled by my curiosity, I asked Lisa "you mentioned that you had siblings, so how did your grandmother decide that it was you that was going to be going to Canada?" Lisa said to me:

My mom in Canada had a miscarriage. At that time, I was still in my biological mom's tummy and you know that Filipino superstition where if someone is pregnant, and the person who is pregnant is jealous of someone then their child will look like the person that they are jealous of. So basically, my biological mom was jealous of my mom in Canada because she had fair skin. My grandmother had noticed that my biological mom would always talk about how my mom in Canada has such nice skin. She noticed this jealousy that was fuming out of my biological mom and so she told her "you already have so many kids, why don't you just let them have this one. She can be the lucky baby to go to Canada" and that is how my grandmother decided that it was me that should go to Canada. It was ultimately my grandmother who orchestrated this whole adoption thing. I don't think that there was really another reason why they had chosen me, but I'm glad that it was me. 
Superstitions and a hyper-focus on appearance is rampant in the Philippines. I remember growing up my mom would tell my caretakers in the Philippines to limit my time outdoors and to always carry an umbrella with me so that I would be protected from the sun. And when I arrived in Canada, I was given copious amounts of whitening soap, all ranging in brand and intensity of bleach that was intended to remove the Filipinx skin, remove the Filipinx body, and to remove our history upon our arrival to Canada. In the Philippines, your skin colour is an indicator of your geographical location, your skin colour becomes a trademark for your occupation, and your skin colour is representative of your socio-economic privilege. In other words, the colour of your skin can be thought of as a trace of mobility/immobility, of who you are - and who you long to be. Darker skin meant less wealth because you had to work extra hard for your money out in the rice fields, stay out late in order to sell street food, or work various jobs that require long periods of exposure to the sun. Lighter skin meant that you did not have to work as hard, and you were privileged enough to work a job in an office that protected you from becoming vulnerable to the sun. As a result of this emphasis on skin colour, it is clear that the desired skin is one that is fair, light, unpigmented, and clear - and all of these words mean white. In Lisa's case, she moved from a village in Pangasinan to a city in Candon, where she lived with multiple family members who took care of her until she ultimately had to move to Canada at the age of seven.

The admiration for fair skin can be linked to the history of the Philippines and the various forms of colonization that the country has endured and continues to experience. Skin bleaching has complicated historical, cultural, sociopolitical, and psychological origins that encourage citizens of the Philippines and other colonies that were colonized by the West to bleach their skin in order to gain access to social capital, which was historically reserved for Whites (Blay, 2011, p. 1). When the Philippines was struggling to meet the demands of repayment to structural- 
adjustment loans from the IMF and the World Bank in the 1960s, President Ferdinand Marcos developed the Labor Export Policy, which created various agencies to aid in the deployment of Filipino/a workers overseas (Pratt, 2012, p. 9), of which Canada is a significant beneficiary. As a result, the Philippines has become a transnational labor hub for Canada, and thus, the imperial presence throughout the country continues to remain and in turn, so does whiteness. The passage of the Labor Export Policy was the start of the institutionalization of Filipino migration. As a result, the families left behind are now being called to take up the care responsibilities of the family member who left.

\section{Multidirectional Care in Lisa's family}

Due to the rise of globalization and the demand for cheap foreign labor, it comes as no surprise that transnational family models continue to emerge. In The Labor of Care: Filipina Migrants and Transnational Families in the Digital Age, Valerie Francisco-Menchavez emphasizes the concept of multidirectional care to describe the ways members of transnational families become resourceful in order to adapt to the ever changing family dynamic under globalization. I will be using Francisco-Menchavez's (2018) definition of "transnational family" to describe the ways in which family members who reside in two or more nation-states organize, operationalize, and sustain the family (p. 5).

Since Lisa was adopted within the family, her mom made sure that she was present in Lisa's life throughout her upbringing in the Philippines. When I asked Lisa how often her parents in Canada were present in her life, she told me: 
my parents always came to the Philippines to see me. My mom was always there since I was born and my grandmother which was my biological mom's mommade sure that my parents who adopted me were present in my life. It was my grandmother who made the final decision that I was going to come to Canada. So, before I was born, my mom in Canada had always been there. This is just what I've been told because she had pictures of me when I was a baby,

The frequent travel between Philippines and Canada, the constant sending of toys abroad, and the ways in which Lisa was cared for within her community in Candon illustrate how multidirectional care operates. Her mom wanted to make sure that Lisa was getting the best care and that she was present throughout her life even if that meant travelling across the world to make it known to Lisa that her mom would always be there for her. Re-reading Lisa's interview transcript, it is very clear to me that her parents in Canada, though they were apart, gave Lisa the secure attachment that she needed considering her abrupt and frequent relocation both geographically within the Philippines and amongst her family. "To me at that time, the moving to Candon because another parent wanted me to come to Canada was confusing for me... so I think that at a very young age, everyone kept telling me that "people in Canada love you so much and that you have another family there" Lisa was being told this and was also being shown an unconditional type of love that expanded beyond the borders of the Philippines. The ability to have your love felt across the world is a type of mothering that does not have conventional language.

I echo Francisco-Menchavez's (2018) focus on how transnational families challenge the idea that "good" care work requires proximity (p. 8). This thinking comes very naturally to me because "the Philippine family rarely follows the nuclear form; for Filipinos, family is upheld by "pakikisama," literally translated as 'being with,' thus placing importance on interpersonal relationships that then bolster a feeling of being in the family" (Francis-Menchavez, 2018, p. 5). In my attempt to wrap up this section of the chapter, I am finding it difficult to pick out "kernels," 
as one of my supervisors Ann Cvetkovich would say, which is to mean, little cornerstone stories that I can then build on, such as a poem or an experience. In this instance, I am making the effort to pick out the kernels in Lisa's interview to highlight the ways her family were operating within the multidirectional care model, which I cannot separate from parts of my own understandings, experiences, and histories. All I know and understand about family centers pakikisama. Pakikisama comes naturally to me; it is all that I have ever known and it is all that I have ever practiced, and I would suggest that pakikisama and multidirectional care are more or less the same thing. Multidirectional care gives us a concept to name the labor which often becomes unrecognized as family members prepare for the changing dynamics within the family unit undergoing migration. And pakikisama gives us the lens to help us see a type of love that knows no bounds. Its vast and passionate love is what makes pakikisama so powerful because pakikisama is not an analytic, it cannot be conceptualized, it cannot be understood, it can only be felt.

Trying to give words to things that do not have conventional language is the challenge that I face in this chapter, and what I believe are the limitations of the current theorizations of the LCP. My only solution is to try to describe them, yet somehow the description does not feel like it is enough - yet I continue to try. Love, intimacy, inclusion, belonging, commitment, acceptance, and trust are words that point to the practice and the feeling of pakikisama, yet they are not enough. I list these words as my attempt to have you understand the depth of Filipino love under rapid migration and globalization because the beauty of pakikisama is rooted in patience. Patience in the hopes that the Philippines will get out of poverty, patience with our hope that our families will be together once and for all, patience when it comes to technology when it will not connect us to our loved ones, patience in waiting for remittances to arrive, and patience when it comes to interpersonal conflict due to family reunification. 
Francisco-Menchavez (2018) uses the work of scholars Catherine Lutz and Lila AbuLughod in their book Language and the politics of emotion put an emphasis on turning to emotionality and understanding it as a politically and socially constructed phenomenon (p. 9). In doing so, we make room for family members to reconfigure their roles in the family dynamic, and make the changes necessary in order for the family to function. Thus, multidirectional care makes room for emotions in transnational studies by making visible the social and reproductive labor that flows between members of transitional families (Francisco-Menchavez, 2018, p. 9). Understanding that emotions have political, economic, and social underpinnings is a step in the right direction towards unpacking the ways in which the impacts of colonialism continue to have an effect on diasporic lives, and also to demonstrate the creative ways in which we continue to both acknowledge our history and create new ways of living.

I join transnationalism scholars of transnationalism in insisting on the importance of the political, economic, and social underpinnings of emotion. Therefore, I invite you, the reader, to reflect on this quote mentioned by an unknown source in The Labour of Care by FranciscoMenchavez "kahit magkalayo kami, hindi kami magkahiwalay" (even if we are separated, we are never apart). I want you to think about someone in your life, dead or alive, that lived in a different city than you. I want you to think about how frequent your communication was, and how you made the relationship work? How did the distance of the relationship make you feel? In what ways did you feel cared for? What challenges arose and how did you combat them? Why did you feel like this relationship was worth the challenges? These questions are prompts in my attempt for you, the reader, to understand the power of pakikisama and the love that Filipinx are capable of giving.

These are some of the challenges that transnational families have to navigate in order to create a sustainable family form. In Lisa's case, all of these questions were addressed by members 
of her family such as Malou, her mom, dad, grandpa, her biological parents, and members of her community. Multidirectional care is a concept that translates a complicated phenomenon experienced by transnational families into Western understandings. It is similar to the Anglicized names racialized persons adopt to reduce how much they stand out among the dominant normative whiteness. Multidirectional care gives us the lens to look at the unacknowledged labor that goes into caregiving. Whereas Pakikisama is a local expression, a rich word with no easy translation, multidirectional care goes some way towards translating its meanings. The power of both concepts helps us understand that Western concepts are not enough when we are discussing care in the context of the Philippines and my desire to write myself into theory. 


\begin{abstract}
AFTERWORD
When we lose faith in things that matter, it is easy to turn to anger. Anger helps us survive when survival seems impossible. I have been very angry throughout my life, and I still am in some ways. I need to be, to live. Yet anger, and its siblings rage and vengeance, have also been poisonous influences in my communities. I've seen people do awful things to one another in the name of anger and revenge, and it never seems to help anyone in the end.

So in the midst of despair, I have come to believe that love - the feeling of love, the politics of love, the ethics and ideology and embodiment of love - is the only good option in this time of the apocalypse. What else do we have? I mean love that is kind but also honest. Love that is courageous and relentless and willing to break the rules and smash the system. Love that cares about people more than ideas, that prizes each and every one of us as essential and indispensable. I mean love that is compassionate and accountable. I mean love that confirms and reaffirms us as complex and fallible yet loveable anyway, love that affirms us as human.

I want to live in love and believe in love. If I have to die, I want to die in love. This whole world might be coming to its end, or it might be in the midst of an enormous and terrifying change that leads to something better. Either way, I want to go through it in love with the people I love.
\end{abstract}

(Thom, 2019, p. 11)

This project responds to the existing research on the increased rates of mental health concerns (including depression) and violence, both inward (i.e. self-harm, substance use, increasing risk taking behaviors) and outward (gender-based violence, aggressive behaviors) among adults who were sponsored as dependents by participants in Canada's Caregiver Program (formerly LCP) (Pratt, 2012, p. 28). Every human wants to feel seen - if the behavior feels like it is for attention, it is actually for connection. I know this to be true because I have gone through phases of violence, mental health concerns, and the behaviors aforementioned. None of them worked in helping me understand my pain as much as love did. It was through radical love and compassion for myself and others that I had the patience to sit with my emotions and move through them with love. 
A central thread throughout this thesis has been how childhood and multidirectional care show us the cracks within broken immigration policies such as Canada's caregiver program and also shed a light through those cracks by keeping emotions, such as love and care, at the forefront. Bringing these ideas back to child and youth studies, I want to foreground Hannah Dyer's central argument about the queer remains of childhood trauma. She uses A Little Life, which is an aesthetic text about a boy named Jude whose childhood experience continues to haunt him and stains his imaginings of the future (Dyer, 2020, p. 86). To further support her belief that there can be no final breaking-off from childhood, Dyer (2020) states:

In the novel, psychical activities are associated with childhood abuse are given aesthetic elaboration that does not seek to repress through a quick cure but rather, understand how the past retains affective intensity in the present. And yet, there is also the reparative potential of re-narrating the history so that its violence are better understood. I have made the case that $A$ Little Life opens up inquiry into how the past is transmitted to the present and in this case, how difficult childhood experience reappears in adulthood. An inference from another time and place, Jude's childhood abuse is correlative to a melancholic adulthood.

Subservience to the law of childhood innocence often requires ignoring the anger and resentment that come with trauma... As A Little Life demonstrates, caring effectively for childhood trauma requires a model of growth and development that holds open space for the non-linearity of trauma's returns. Allowing trauma's returned content to find expression is a mode of help that can be offered by concerned adults in an effort to be with children as they regain trust in a failing world, rather than repress its horrors...A traumatic event's ensuing damage requires an innovative therapeutic, pedagogical, and methodological approach. In asking how a child can love a world that has shown its inability to offer protection when it is most needed, the novel insists that childhood is inextricable from adulthood experience.

(Dyer, 2020, p. 101)

Just as A Little Life has shown, childhood experiences are correlative to adult experiences. I include Dyer's lengthy quote because this thesis is my attempt to showcase how both the Canadian 
and Filipino states endorsed oppressive immigration schemes such as the LCP. The LCP program started in 1992, then changed to the CP, then the Care Pilot (2019), and now the Interim Pathway (2019). These changes occurred because of strong political solidarity from activist organizations such as Migrante Ottawa and Anakbayan Ottawa, whose mission is to unite youth from different sectors and communities in the Filipino diaspora. Geraldine Pratt, Ethel Tungohan, Amrita Hari, Valerie Francisco-Menchavez, Hannah Dyer, Casey Mecija, and many other scholars whose work I mentioned extensively in this thesis continue to engage in advocacy pertaining to labour rights of migrants and their families.

My personal proximity to this project makes my research particularly transformative, as I interviewed five adults, who, as children, like myself, were sponsored for permanent resident status in Canada by former participants of the LCP (their mothers). I aim to continue building on the work of transnational feminist scholars, including Ethel Tungohan and Geraldine Pratt, who have published extensively on the LCP and care as gendered and affective labour. I engaged with scholars of critical childhood development such as Hannah Dyer and Casey Mecija), who suggest that "there is a lot to be said about children who must witness their mother privilege the care of another child over their own" (Dyer \& Mecija, 2018, p. 545). An interesting extension of this project would be to explore how former sponsored dependents of the LCP who are now parents themselves understand parenthood, family, and childhood development. Methodologically, longitudinal feminist ethnography would provide a better and more complete understanding of the lasting impact childhood development - which, here, is informed by racism, migration, and economic uncertainty - has on adulthood. Overall, this thesis has allowed me to further bridge the gaps among the literature on Filipinx diaspora, child and youth studies, and transnational motherhood and care. 
In keeping with the unique narrative style, I have used in this thesis, my conclusion is rooted in hope and grounded in love, as the way out of the pain that brought me to this project. Below are my love letters to my interview participants. I want to thank them for sharing their stories because it is through narration that we take control of the stories we tell ourselves about ourselves. Our experience challenges normative Western definitions of childhood. We were never 'children left behind'- rather, we are children with a multitude of resources, people, and networks.

Dear Vendeta: I want to first thank you for being so kind and honest with me. Your relationship with your mom reminded me of the relationship that I have with mine. Except you were braver and more empathetic. I admire how you are so driven to succeed and that this drive is fueled by gratitude. You saw your mom work hard, you saw her clean houses on Christmas eve, and through those experiences, you were able to understand her reasons for leaving.

Dear Chini: Thank you for reminding me of the importance of queer kinship and living with integrity. You remind me that in queerness, there is a home made by those seeking to feel safe, understood, and seen. You are resourceful and a force to be reckoned with because you have a strong sense of self. I look up to you and the ways you kept yourself safe-emotionally, financially, and physically. Your capacity for love is something that I aspire to obtain because it is unconditional. You forgave your mom for leaving, and you forgave your dad despite his homophobic aggressions towards you. Thank you for teaching me how to remain soft.

Dear Lisa: Reflecting on our interview, I am reminded of just how strong Filipinx communities are. Although there are a lot of superstitions and beliefs, they serve as a testament to the history 
of the Philippines and the many forms of colonization the country and its people have endured. Despite the colonial legacy, the one thing that remains unchanged is our sense of community. Filipinos will always ask you 'have you eaten?' when posed this question, and what we are really trying to tell you is that we love you. We are glad that you are here, let me take care of you. 


\section{WORKS CITED}

Anzaldúa, G. (1991). “To(o) Queer the Writer-Loca, escritora y chicana.” In Living chicana theory: 263-276.

Blay, Y. (2011). Skin bleaching and global White supremacy: by way of introduction. Journal of Pan African Studies, 4(4), 4-46.

Bakker, I. (2007). Social Reproduction and the Constitution of a Gendered Political Economy. New Political Economy, 12(4), 541-556.

Bernstein, R. (2017, July 16). Let Black Kids Just Be kids. New York Times. https://www.nytimes.com/2017/07/26/opinion/black-kids-discrimination.html.

Berger, J. (1980 [1974). Understanding a Photograph. In Geoff Dyer (Eds). Understanding a Photograph, 24-27.

Berlant, L. (2011). Cruel Optimism. Duke University Press.

Banerjee, R., Kelly, P., \& Tungohan, E. (2017). Assessing the Changes to Canada's Live-in Caregiver Program: Improving Security or Deepening Precariousness?. Pathways to Prosperity.

Baldassar, L., \& Merla, L. (2013). Transnational families, migration and the circulation of care: understanding mobility and absence in family life. Routledge.

Baldassar, L. (2007). Transnational families and the provision of moral and emotional support: The relationship between truth and distance. Identities,14(4), 385-409.

Cvetkovich, A. (2003). An archive of feelings trauma, sexuality, and lesbian public cultures. Durham, NC: Duke University Press.

Carlos, J. (2016). Canada's (Live-In) Caregiver Program: Perceived Impacts on Health and Access to Health Care among Immigrant Filipino Live-in Caregivers in the Greater Toronto Area, Ontario, Canada. ProQuest Dissertations Publishing.

Canadian Immigration Law Firm. (2017, May 26). Canada Live In Caregiver 2017 Program Update. https://www.canadim.com/blog/live-in-caregiver-2017-update/.

Cohen, R. (1994). A brief history of racism in immigration policies for recruiting domestics. Canadian Woman Studies, 14(2), 83-86.

Dyer, H., Mecija, C. 2018. Leaving to Love: Filipina Caregivers and The Queer Kinship of Transnational Childcare, World Futures, 74(7-8), 542-558. 
Dyer, H. (2020). Queer Aesthetics of Childhood Asymmetries of Innocence and the Cultural Politics of Child Development. Rutgers University Press.

Drolet, N. (2016). An Overview of Canada's New Caregiver Program: A Shift From Permanence to Precariousness. Canada's Immigration \& Citizenship Bulletin, 6(27), 1-4.

Eng, D., Halberstam, J., \& Muñoz, J. (2005). “What's Queer About Queer Studies Now?” Social Text23 (3-4 (84-85)): 1-17.

Felsenthal, J. (2016, April 5). Ebony G. Patterson Confronts Race and Childhood at the Studio Museum in Harlem. Vogue. https://www.vogue.com/article/ebony-g-patterson-studiomuseum-harlem.

Farrales, M. (2017). Delayed, deferred and dropped out: geographies of Filipino-Canadian high school students. Children's Geographies, 15(2), 207-223.

Francisco-Menchavez, V. (2018). The Labor of Care Filipina Migrants and Transnational Families in the Digital Age. University of Illinois Press.

Garlen, J. (2019). Interrogating innocence: "Childhood" as exclusionary social practice. Childhood (Copenhagen, Denmark), 26(1), 54-67.

Government of Canada. (n.d.) Improving Canada's Caregiver Program. https:/www.canada.ca/en/news/archive/2014/10/improving-canada-caregiverprogram.html\#wb-cont.

Hari, A. (2014). Temporariness, Rights, and Citizenship: The Latest Chapter in Canada's Exclusionary Migration and Refugee History, Refuge, 30(2), 35-44.

Hewitson, J. (2009). Documenting Disasters: Rothstein's "Steer Skull” and the Use of Photographic Evidence in Environmental and Political Narratives. Photographs, Histories, and meanings, (43-58).

Heymann, B. (Director). (2006). Paper Dolls [Motion Picture]. United States.

Hooks, b. (1991). Theory as liberatory practice. Yale Journal of Law and Feminism, 4(1), 1-12.

Immigration, Refugees and Citizenship. (n.d.). Caregivers will now have access to new pathways to permanent residence. Government of Canada. https://www.canada.ca/en/immigration-refugees-citizenship/news/2019/02/caregiverswill-now-have-access-to-new-pathways-to-permanent-residence.html. 
Immigration, Refugees, and Citizenship. (n.d.). Interm Pathways for Caregivers:

Who Can Apply. Government of Canada. https://www.canada.ca/en/immigrationrefugees-citizenship/services/immigrate-canada/caregivers/interimpathway/eligibility.html\#child.

Immigration, Refugees, and Citizenship. (n.d.). Hire a home child care provider or home support worker. Government of Canada. https://www.canada.ca/en/immigrationrefugees-citizenship/services/work-canada/hire-permanent-foreign/in-homecaregiver.html.

Immigration, Refugees, and Citizenship. (n.d.). What is a Labour Market Impact Assessment?. Government of Canada. https://www.cic.gc.ca/english/helpcentre/answer.asp?qnum=163\&top=17.

Johnson, E. P. (2001). “'Quare' studies, or (almost) everything I know about queer studies I learned from my grandmother." Text and Performance Quarterly 21(1): 1-25.

Labadie-Jackson, G. (2008). Reflections on domestic work and the feminization of migration. Campbell Law Review, 31(1), 67-90.

Lehr, V. (1999). Queer Family values: debunking the myth of the nuclear family. Temple University Press.

LeBaron, G. (2010). The political economy of the household: Neoliberal restricting, enclosures, and daily life. Review of International Political Economy: RIPE, 17(5), 889912.

Joan, A. (1988). Class, Gender, and the relations of Distribution. Signs: Journal of Women in Culture and Society, 13(3), 473-497.

Manalansan, M. (2003). Global divas Filipino gay men in the diaspora. Duke University Press.

McCann, H. (2016). Epistemology of the Subject: Queer Theory's Challenge to Feminist Sociology.WSQ: Women's Studies Quarterly, 44(3): 224-243.

Mejia, C. (2020). Blank Space and "Asymmetries of Childhood Innocence". Sounding Out! Retrieved from https://soundstudiesblog.com/tag/casey-mejia/

Migrant Workers Alliance for Change, (2019, May 18). Policy Recommendations: Temporary Foreign Workers Program in Canada: Migrant Worker Priorities 2019). https://migrantworkersalliance.org/wp-content/uploads/2019/06/Final_-Migrant-WorkerPolicy-Priorities-May-2019.pdf.

Migrante Ottawa. (n.d.). Filipino Migrants in Ottawa. http://migranteottawa.org/. 
Narayan, U. (1989). The project of feminist epistemology: Perspectives from a nonwestern feminist. In A.M. Jaggar \& S. Bordo (Eds.), Gender/Body/Knowledge: Feminist Reconstructions of Being and Knowing. Rutgers University Press, 256--69

Nichols, L. \& Tyyskä, V. (2015). Immigrant Women in Canada and the United States. In Hobbs, M., \& Rice, C (Eds), Gender and Women's Studies, 609-616.

Pratt, G. (2012). Families apart migrant mothers and the conflicts of labor and love. Minneapolis: university of Minnesota Press.

Pratt, G. (2015) 'Between colonialism and settler colonialism: Filipino youths in Canada' Singapore Journal of Tropical Geography 36(3), 305-307.

Pratt, G., \& Johnston, C. (2014). Filipina domestic workers, violent insecurity, testimonial theatre and transnational ambivalence. Area (London 1969), 46(4), 358-360.

Rose, G. (2016). Discourse analysis 2: Institutions and Ways of Seeing. In Visual Methodologies. London: Sage, pp. 220-252.

Rivers-Moore, M. (2016). Gringo Gulch: Sex, Tourism, and Social Mobility in Costa Rica (Vol. 57734). University of Chicago Press.

Robinson, K. (2012). Innocence, Knolwedge and the Construction of Childhood The contradictory nature of sexuality and censorship in children's contemporary lives. Taylor and Francis.

Rajkumar, D., Berkowitz, L., Vosko, L. F., Preston, V., Latham, R. (2012). At the TemporaryPermament Divide: How Canada Produces Temporariness and Makes Citizens through Its Security, Work, and Settlement Policies. Citizenship Studies, 16(3-4), 483-510.

Salami, B., \& Nelson, S. (2014). The downward occupational mobility of internationally educated nurses to domestic workers. Nursing Inquiry, 21(2), 153-161.

Temporariness in Canada: Establishing a Research Agenda. (2013). CERIS - The Ontario Metropolis Centre.

Telephone Explosion Records. (2020, May 25). Pantayo - Heto Na (Official Video) [Video]. Youtube. https://www.youtube.com/watch?v=4_khrQsXQIM.

Tungohan, E. (2013). "Reconceptualizing Motherhood, Reconceptualizing Resistance: Migrant Domestic workers, transnational hyper-maternalism and activism", International Feminist Journal of Politics, 15(1), 39-57. 
Tungohan, E., \& Hanley, J. (2019). Introduction to the themed section: a question of caring ethical and policy dilemmas arising from care migration. International Journal of Care and Caring, 3(2), 225-227.

Tungohan, E. (2019). Global care chains and the spectral histories of care migration.

International Journal of Care and Caring, 3(2), 229-245.

Thom, K. (2019). I hope we choose love: a trans girl's notes from the end of the world. Arsenal Pulp Press.

Woodward, S. (2016). Object Interviews, material imaginings and "unsettling" methods: interdisciplinary approaches to understanding materials and material culture. Qualitative Research, 16(4), 359-374. 


\section{Appendix A: Interview Guide}

1. I want to get a sense of who you are. Can you tell me a bit about yourself? Where did you grow up? How do you identify?

2. Can you tell me why you brought this item?

3. What are some memorable moments from your childhood in the Philippines?

4. How did you understand family when you lived in the Philippines?

5. How old were you when your sponsoring parent moved to Canada?

6. How did your sponsor/parental guardian tell you that they were leaving to go to Canada?

7. Who took care of you in the Philippines while your parent/sponsor was working in Canada?

8. Were you always aware that you were going to come to Canada permanently? If not, when did you start to think about possibly moving to Canada? Or, when did you first discuss with your family in the Philippines and/or in Canada about moving?

9. How did you communicate with your parent/sponsor in Canada? How often did you talk to them? How often would they visit?

10. Would your parent in Canada ever discipline you while being away? What did you miss most about them?

11. Would your sponsoring parent still be a part of your daily life and important activities while living and working in Canada? If yes, how would they do this? Please provide some specific examples if possible.

12. How would you describe your relationship with your sponsoring parent when they were living in Canada? 
13. How would you describe your relationship with the person(s) who took care of you in the Philippines while your parent/sponsor was away living and working in Canada?

14. How did you prepare for your move to Canada? How long did this process take?

15. What were you most excited about when moving to Canada? What were you most afraid of or anxious about?

16. What were some of the initial challenges you faced after moving to Canada? How have some of these challenges changed since you have been living here?

17. What did it feel like attending school in Canada? How similar or different was it from your experiences in the Philippines?

18. How would you describe your relationship with your sponsoring parent once you were living with them in Canada?

19. How would you describe your relationship with the person(s) who took care of you in the Philippines after moving to Canada?

20. Do you communicate with the person(s) who took care of you in the Philippines since moving to Canada? If yes, how? What is the frequency of these communications? What do you miss most about them?

21. Did your understandings of family change since coming to Canada?

22. What are some memorable moments of the parts of your childhood spent in Canada?

23. How similar or different are these memorable moments in Canada than your memories of the Philippines?

24. Have you visited the Philippines after moving to Canada? If so, at what age and for how long? How would you describe your experience of the visit? 
25. Do you maintain any connections to the Filipino community in Canada? If yes, in what ways and how often?

26. In what ways would you say your life and relationships change since moving to Canada? How would you describe these changes?

27. Do you share your migration story with others, i.e. being sponsored through the Live-in Care giver program (LCP)? If yes, with whom? If not, why not?

28. Have you talked to your sponsoring parent about their experiences of the LCP? Who initiated these conversations? How would you describe these conversations? Have you shared their experiences of the LCP with others? If so, who?

29. How do you understand success? Does your understanding vary in different contexts? If yes, please describe with specific examples.

30. What are your hopes and dreams for your future?

31. What motivated you to participate in this study?

32. Is there anything you would like to add?

33. Do you have any questions for me? 
APPENDIX B: Demographics

\begin{tabular}{|c|c|c|c|}
\hline Pseudonym & Age & Gender Identity & $\begin{array}{c}\text { Arrival in } \\
\text { Canada }\end{array}$ \\
\hline Ariel & 23 & Female & December 2016 \\
\hline Lisa & 23 & Female & $\begin{array}{c}\text { At age seven } \\
\text { years }\end{array}$ \\
\hline Chini & 25 & Male/non-binary & September 9, \\
& & & 2010 \\
\hline Luke & 22 & Non-binary & August 2015 \\
\hline Vendeta & 28 & Gay & September 2015 \\
\hline
\end{tabular}

